\title{
Corporate taxes and high-quality entrepreneurship
}

\author{
Ana Venâncio (D) • Victor Barros • Clara Raposo
}

Accepted: 5 October 2020 / Published online: 12 November 2020

(C) The Author(s) 2020

\begin{abstract}
We examine the impact of corporate taxation on entrepreneurship, using a quasi-natural experiment, which substantially reduced the corporate tax rate for start-ups located in inland municipalities in Portugal. Using a difference-in-differences approach and IV regression, we find that the tax reform increased firm entry and new firm job creation. The entrepreneurs who took advantage of this tax reform are relatively older, and are better-educated individuals. Their start-ups are relatively larger, more productive, and are more likely to survive the first 3 years. These findings suggest that corporate taxation is an imperative constraint for entrepreneurship, particularly for high-quality entrepreneurs. These better-educated individuals find it easier to overcome the hurdles of tax legislation and to make use of the opportunities created by a specific tax reform.
\end{abstract}

Keywords Tax reform - Corporate taxes · Firm entry · Job creation $\cdot$ High-quality entrepreneurship

JEL classifications $\mathrm{H} 25 \cdot \mathrm{L} 26 \cdot \mathrm{M} 13 \cdot \mathrm{J} 24$

\footnotetext{
A. Venâncio $(\bowtie) \cdot V$. Barros $\cdot$ C. Raposo

ISEG-Lisbon School of Economics and Management, Universidade de Lisboa, and ADVANCE/CSG, R. Miguel Lupi 20, 1249-078 Lisbon, Portugal

e-mail: avenancio@iseg.ulisboa.pt
}

\section{Introduction}

The effect of taxes on entrepreneurial activity has enjoyed a recent resurge in the empirical literature (Block 2016; Braunerhjelm and Eklund 2014; Darnihamedani et al. 2018). Empirical evidence links higher corporate taxes with slower economic growth and also lower productivity, innovation, investment, firm creation, and employment (Djankov et al. 2010; Da Rin et al. 2011; Bacher and Brülhart 2012; Baliamoune-Lutz and Garello 2014; Haufler et al. 2014; Belitski et al. 2016; Mukherjee et al. 2017). Therefore, reducing taxes is perceived to be an effective tool for encouraging firm creation and employment. However, despite the perceived belief that tax reductions promote entrepreneurial activity and address economic growth, there is still ambiguity regarding the type of ventures and entrepreneurs which take advantage of such tax reforms.

In this paper, we evaluate the effect of corporate taxes on entrepreneurship. Similar to previous studies, we investigate the impact of corporate taxes on firm formation and new firm job creation. However, contrary to previous studies, we take the additional step of exploring the characteristics of the founders and of the startups which took advantage of a specific tax reform.

Portugal provides an excellent context for evaluating the effect of taxes on entrepreneurship, for several reasons. First, Portugal offers an opportunity to assess the role of taxes in firm formation in a "neutral" tax setting. The majority of studies are based on data from the 
USA, ${ }^{1}$ which is a country where the tax structure rewards risk-taking and tax-driven entrepreneurship, by making it particularly attractive for high-income earners to become self-employed, resulting in them paying less tax (Cullen and Gordon 2007). Portugal operated a flatrate corporate income tax system, and potential losses are generally deductible against the future gains of the firm. Therefore, tax progressivity is not a concern during the period of the study (Gentry and Hubbard 2000). Second, we are able to evaluate variations in the corporate tax rate at the municipality level. Before 2001, the corporate tax rate faced by start-ups in Portugal was $34 \%$, and then, in 2001, Portugal implemented the "Portuguese Tax Benefits for Inlandness" (Beneficios Fiscais à Interioridade), which reduced taxes to $25 \%$ for all start-ups located in inland regions. After 2004, the tax rate was reduced to $15 \%$, and then, after 2007, it was further reduced to $10 \%$. Third, we combine rich municipality level data with both individual- and firm-level data for the period between 1997 and 2011. We use a detailed mandatory survey, which covers virtually all firms and employees in the Portuguese private sector, and explore the variation in tax burdens within municipalities and across time, in order to analyse the impact of corporate taxation on firm formation and job creation.

Our results suggest that the Portuguese tax reform increased firm entry in the treated municipalities under analysis by approximately 41 percentage points and new firm job creation by 24 percentage points on a monthly basis. At the country level, this effect is of economic significance. Over 3 years, the tax reform could have increased the number of new firms, at the national level, by 29,150 , and new firm job creation by approximately $223,500 .^{2}$

One possible explanation for the increase in firm entry is that taxes represent recurring costs which reduce the gains from entrepreneurial profit and thus discourage risk-taking and innovative entrepreneurs (Hansson 2012; Gentry and Hubbard 2000; Darnihamedani et al. 2018). Another explanation could be that corporate

\footnotetext{
${ }^{1}$ Exceptions include Hansson (2012) evaluating Sweden's fiscal reform and Bacher and Brülhart (2012) analysing the Swiss fiscal reform.

${ }^{2}$ Our approximation is derived by assuming a $0.41 \%$ entry rate $\times$ an average 960 incumbent firms per municipality $\times 278$ municipalities $\times$ 36 months $\times$ an average survival rate of 0.85 (which is corroborated by the fact that we estimate a 36-month survival rate of 0.90 for start-ups established after the reform). With regard to new firm jobs creation, we adopted a $0.24 \%$ new firm job creation rate $\times$ average 9460 employees per municipality $\times 278$ municipalities $\times 36$ months.
}

taxes reduce the amount of internal funding available for capital investments and the hiring of skilled employees. Additionally, we argue that better-educated individuals possess the required knowledge to make use of the opportunity created by the tax reform and to understand the complexity of the tax systems. To investigate this concern, we take advantage of a detailed individual-level database. We select start-ups which were established between 1997 and 2011. For each firm, we gather comprehensive information regarding entry year, location, industry, number of employees, and founder characteristics. Next, we identify the founders and evaluate their socio-demographic characteristics. We find that start-ups established in municipalities that reduced the corporate tax rate are more likely to survive their first 3 years and are relatively larger, with a statistically significant result for firms with 3 to $10 \mathrm{em}$ ployees. The positive effect of the tax reform on firm entry appears to be much more common in the construction and trade (retail and wholesale) sectors. The entrepreneurs introduced to the market are better educated, and aged between 40 and 60 years old. These individuals are better qualified to identify and take advantage of opportunities created by a tax reform. To sum up, our study suggests that corporate taxation constrains highquality entrepreneurs. For the purposes of this study, we define high-quality entrepreneurs as being bettereducated individuals who start a business in any industry but with higher chances of survival and better performance.

We contribute to the previous literature on entrepreneurship and taxation by taking advantage of a quasinatural experiment, by looking at a tax reform in a single country, which significantly reduced corporate taxes in some specific municipalities. Accordingly, we are able to more effectively isolate the impact of corporate taxes on entrepreneurial activity. Previous studies have analysed several countries where tax cuts are often part of a larger policy package and where other economic and social variables can contribute to influencing the results. Second, we use a difference-in-differences approach, combined with instrumental variable regression. We recognize that the treatment was not exogenous, and, to mitigate this, we introduce an instrument to help address the endogeneity issue. Third, our results suggest that the impact of the Portuguese tax reform appeared to be particularly large in magnitude. This is in line with previous literature which found that tax policies can be important determinants of entrepreneurial activity; 
however, it departs from previous studies that argue that the impact on entrepreneurship of corporate taxes was small, or even meaningless (Bruce and Mohsin 2006). Fourth, we analyse how this tax reform affected the characteristics of both the entrepreneurs and the startups. Previous studies suggest that higher corporate tax rates increase the amount of capital of new firms (Da Rin et al. 2010) and the informal sector (Bacher and Brülhart 2012), but that they reduce innovative entrepreneurship (Darnihamedani et al. 2018). We add to the literature by suggesting that the impact of the tax reform was observed mostly among better-educated entrepreneurs who established better-performing ventures. Corporate tax rates seem to constrain those firms which are most likely to survive and have greater sales per employee.

The lessons learnt in this paper are likely to extend beyond the Portuguese context. Several countries continue to implement proentrepreneurship policies without understanding their effects on economic growth and new venture creation. The extent to which corporate taxes influence entrepreneurial activity and type of entrepreneurship requires further investigation to facilitate the design of better policies. As governments benefit considerably from collecting taxes which in turn are used to provide public goods, they also want to avoid the risk of deterring firm entry, particularly those founded by high-quality entrepreneurs (Lee and Gordon 2005). A small set of high-growth companies accounts for the majority of job creation and economic growth (Shane 2009), which means that it is even more relevant to undertake a thorough consideration of the effect of taxes on the type of entrepreneurship. In addition, our research responds to a call for a better understanding of the level of success of new ventures created as a result of tax reductions (Block 2016; Darnihamedani et al. 2018). Furthermore, understanding the factors involved in business location decision is a key issue for regional policy.

The remainder of this paper is structured as follows. In Section 2, we briefly review the literature on the impact of taxes on entrepreneurship. Section 3 presents the main hypothesis of our study. Section 4 describes the Portuguese corporate tax reform and the institutional setting. In Section 5, we describe the data, and Section 6 presents the empirical strategy and the results. Section 7 concludes.

\section{Literature review}

The number of studies on the effects of taxation on entrepreneurship has grown significantly in recent years, mainly due to the greater availability of data. Previous research has focused mostly on the effects of personal income on self-employment (see for example Baliamoune-Lutz and Garello 2014) and to a lesser extent on the effects of corporate income taxes on entrepreneurship. ${ }^{3}$ Corporate tax is levied on incorporated firms, whereas personal income taxes are levied on income generated by unincorporated firms, salaried employees, and the self-employed. Other studies define a more aggregate measure of taxes, which, besides including the corporate tax rate, also includes VAT, personal taxes, and other taxes (Djankov et al. 2010; Da Rin et al. 2011).

Time-series studies generally conclude that higher personal income or payroll tax rates cause higher rates of self-employment (Long 1982a, 1982b; Moore 1983; Blau 1987; Parker 1996; Cowling and Mitchell 1997; Robson 1998; Parker and Robson 2004). The explanation for this positive relationship rested on the idea that high tax rates drive employees out of paid employment into entrepreneurial ventures, where they can more easily avoid or evade taxes. However, recent studies fail to show consensus (Bruce et al. 2020), as some argue that taxes have a substantial adverse effect on entrepreneurship as the expected gains from risky business ventures are reduced (Briscoe et al. 2000; Fölster 2002; Moore 2003; Gentry and Hubbard 2005; Djankov et al. 2010; Fossen and Steiner 2009; Hansson 2012), whereas other studies suggest that tax rate policies are an ineffective tool for generating meaningful changes in entrepreneurial activity (Bruce and Mohsin 2006). Either way, these studies present several inference problems, as they fail to address the autocorrelation and endogeneity problems (Bruce and Mohsin 2006).

To overcome these limitations, other studies have examined longitudinal micro-level data; however, their results have also been inconclusive (Bruce 2000, 2002; Gentry and Hubbard 2000; Moore 2003; Schuetze 2000; Carroll et al. 2000). While some of these studies conclude that higher income tax rates have an ambiguous effect on self-employment rates, there is a growing

\footnotetext{
${ }^{3}$ Besides income and corporate taxes, entrepreneurs also face capital gain and capital income taxes, as well as wealth and inheritance taxes (Block 2016).
} 
consensus that a positive correlation exists between taxes and entrepreneurial entry (Schuetze 2000; Bruce 2000, 2002). The latter studies support the argument that high corporate income tax rates reduce profits for incorporated businesses and thus reduce the incentive for individuals to become entrepreneurs and establish new firms. Higher and more progressive tax rates increase the opportunity costs of entrepreneurship and reduce the entrepreneur's payoff. Other studies suggest a nonlinear relation between taxes and firm entry rates, such that the positive effect is only at work below a tax level threshold (Da Rin et al. 2011).

While useful, the previous cross-country and timeseries approaches are not a substitute for empirical evaluations of actual policy shifts which reduced corporate tax rates for start-ups in one single country. Compared with the previous literature, we are able to evaluate a simple and dramatic policy shift and evaluate its impact on firm entry and job creation and also the kinds of startups and entrepreneurs which seem to have benefited from the tax reform. Previous research suggests that high corporate income tax rates increase the total assets of incorporated firms (Da Rin et al. 2010), as well as the size of the informal sector (Bacher and Brülhart 2012), suggesting that corporate taxes function as a barrier to marginal entrepreneurs. In contrast, Darnihamedani et al. (2018) find that corporate taxes negatively affect innovative entrepreneurship. Beyond these studies, little is known about the characteristics of the entrepreneurs and the quality of the start-ups which are introduced into the market when governments reduce the rate of corporate tax. This is an important gap in the literature, as the impact of tax reforms is a function not only of the number of new firms, but also of their quality.

\section{Corporate taxes and high-quality entrepreneurship}

Corporate taxes have the effect of deterring firm entry, as they influence the supply of potential entrepreneurs and their consequent effort to the economy as a whole.

Corporate taxes influence an individual's career decision by increasing the opportunity costs of entrepreneurship. The occupational choice model suggests that individuals compare their potential earnings from entrepreneurship with those derived from being an employee (Lucas Jr 1978; Kihlstrom and Laffont 1979) and that individuals then pursue the occupational option with the highest income. As entrepreneurial returns are squeezed by corporate taxes, the option of becoming an entrepreneur becomes less appealing when compared to working as a hired employee. Although entrepreneurs have more opportunities to avoid paying taxes than employees (Kamleitner et al. 2012), corporate taxes are seen to be part of the entrepreneur's mental earnings and are perceived as being a recurring loss (Darnihamedani et al. 2018).

Furthermore, high corporate tax rates pose an entry barrier to entrepreneurs as they increase the costs of starting a business and consequently deter individuals who are unable to raise the required capital. Due to high agency costs, new ventures rely heavily on retained earnings (Henrekson and Sanandaji 2011). High corporate tax rates diminish a part of these earnings and make it more difficult for entrepreneurs to raise the required capital. In summary, corporate taxes lower entrepreneurial returns and increase entry barriers. Consequently, we expect:

Hypothesis 1. A reduction in corporate taxes will have a positive effect on firm entry.

Taxes also influence the type of entrepreneurial activity. Entrepreneurs' strategic decisions are tax-sensitive, examples being their willingness: to introduce new products and services (Darnihamedani et al. 2018), to invest in corporate investments and capital formation (Djankov et al. 2010; Bhattarai et al. 2017), and to hire new employees (Carroll et al. 2000).

High-quality ventures usually require greater capital investment and more skilled employees, irrespectively of the industry where they operate. Nonetheless, corporate taxes reduce the amount of funding available to invest in these resources, making it more difficult for entrepreneurs to finance their ideas.

Moreover, tax-financed welfare systems are usually associated with extensive safety-net programmes (Baumol et al. 2007), which generally represent a culture that does not reward risk-taking behaviour and entrepreneurial investments. These safety-net programmes usually insure wage employment, but not entrepreneurial investment (Ilmakunnas et al. 1999). In addition, several studies conclude that there is a negative relationship between welfare states and household savings (Fölster 2002), where savings are usually used as source of funding to start a new venture. High corporate taxes therefore deter high-quality entrepreneurs by 
discouraging them from saving and investing in risktaking initiates. In fact, previous literature finds that corporate taxes reduce the expected gains from risky business ventures (Briscoe et al. 2000; Fölster 2002; Gentry and Hubbard 2000; Fossen and Steiner 2009; Hansson 2012). In contrast, a reduction in the corporate tax rate is expected to increase entrepreneurial investments and capital accumulation and, at the same time, encourage the entry of higher-quality firms.

Complex rules, especially regarding taxes, are difficult to understand. Tax systems tend to grow increasingly complex and opaque over time. To give an example, Sull and Eisenhardt (2015) asked 45 tax professionals to compute one fictional family's tax bill, which resulted in 45 completely different estimates, with differences ranging in the tens of thousands of dollars. To navigate the tax system, individuals require tacit knowledge to understand the meanders of taxation. Corporate taxes have "an irreducible core of complexity" (Weisbach 2007) and create significant administrative and compliance costs and reduce business entry (Weber 2015). Therefore, better-educated founders should have the required "absorptive capacity" to understand and take advantage of possible opportunities created by changes in tax laws (Balconi and Fontana 2011). Better-educated founders can also search for specificities in the tax code (such as tax credits), which become useful for subsequent entrepreneurial activity, and eventually lead to enhanced performance of ventures. On the other hand, such entrepreneurs are more likely to seek out professional tax advice and thus may be more aware of the various provisions in the tax code. Better-educated individuals are more likely to possess the required knowledge to tackle the opportunity created by a tax reform.

Nonetheless, better-educated individuals face higher opportunity costs to transition to entrepreneurship, as they tend to have better-paying jobs. Besides comparing the returns, potential entrepreneurs also consider the risk of the returns. The extent to which one of these effects outweighs the other depends on the individual's preferences between risk and return. Although wage income is typically more stable than the returns from an entrepreneurial venture, the total potential gains are higher in the case of entrepreneurship. Consequently, a reduction in corporate tax rates then increases the rate of entrepreneurship, particularly among those more willing to take risks (Kihlstrom and Laffont 1979), as they are more able to identify and act on the opportunities created by a tax reform.

To sum up, a reduction in corporate taxes encourages risk-taking and better-educated entrepreneurs, as it is they who are more able to easily overcome the hurdles of tax legislations and raise the required capital. Therefore, we expect:

Hypothesis 2. A reduction in corporate taxes will have a positive effect on high-quality entrepreneurship.

\section{The Portuguese tax reform}

To better frame the empirical results, we now proceed to briefly describe the Portuguese tax reform. ${ }^{4}$ Before 2001, all start-ups in mainland Portugal were liable to a tax rate of 34\%. The Portuguese Budget for 1998 proposed the implementation of fiscal benefits for micro and small firms located in inland regions, in order to encourage more economic activity in less-favoured regions and to prevent human migration. Leveraging on this suggestion, the main opposition party (the PSD party) presented a bill which was approved in Parliament, with the votes of all opposition parties and the abstention of the party in government (the PS party). The bill went on to be passed with unanimity in the final vote, the result being the promulgation in 2001 of Law No. 171/99 on "Tax Benefits for Inlandness" (Beneficios Fiscais à Interioridade) with the aim to promote firm formation and job creation in the inland regions.

Figure 1 compares the marginal tax rates levied on start-ups located in mainland Portugal before and after the tax reform. The 2001 tax reform decreed a tax rate of $25 \%$ for the first 5 years of activity of start-ups located in treated municipalities, compared to $34 \%$ for start-ups located in non-eligible municipalities. ${ }^{5}$ However, the gap in the tax rate between treated and control

\footnotetext{
${ }^{4}$ Appendix 1 Table 9 provides a detailed summary of the different laws enacted between 1997 and 2011 related to the corporate tax reform.

${ }^{5}$ In addition to a reduction in the corporate tax rate, this reform also introduced other incentives, which included: a loan for developing municipality infra-structures; a special credit line for micro and small firms; exemptions from paying social security; and, exemptions from paying local property taxes for individuals aged between 18 and 35 , should they purchase a house in an inland municipality.
} 
municipalities diminished between 2002 and 2003, and all start-ups became liable for the same tax rate of $25 \%$ in 2004. In 2005, the newly elected government supported by the PSD party decided to extend the tax benefits for inlandness for more years. After several debates, the "Tax Benefits to Inlandness" law was included in the Portuguese Tax Benefits Code, and the tax rate for start-ups was further reduced to $15 \%$, with this benefit being extended up until 2007 (Law No. 55-B/ 2004). In 2008, the tax rate for new firms located in inland municipalities was further reduced to $10 \%$. Finally, in 2012, which was posterior to the period under analysis in our study, the reduced tax rate was cancelled, and all start-ups in mainland Portugal became liable for a tax rate of $25 \%$.

However, the reduced tax rate did not apply to ventures established in the sectors of agriculture, fishing, mining, manufacturing of coke (fuel products), and transportation. The tax reform applied to start-ups whose headquarters and the majority of employees were located in eligible (inland) municipalities. We use this reform as a quasi-natural experiment to split the country into control (coastal) and treated (inland) municipalities. A map of mainland Portugal with the treated and control municipalities is portrayed in Fig. 2. To make our analysis more comparable, we only consider municipalities located on the border of the regions impacted by the tax reform. ${ }^{6}$ Potential entrepreneurs living in a control municipality could easily move to a nearby treated municipality to establish their start-up. Although this concern is plausible, Kulchina and Venâncio (2019) show that $90 \%$ of Portuguese entrepreneurs establish their ventures in the same municipality where they previously worked. Our data presents a similar ratio.

By the end of 2001, 38 municipalities reduced their corporate tax rate and 33 municipalities maintained their corporate tax rate. In total, we evaluate 71 municipalities (out of 278 municipalities in mainland Portugal). The treated and control municipalities are not spread throughout the whole of mainland Portugal. At first, the government defined several criteria to select the

\footnotetext{
${ }^{6}$ Our results are robust, considering the full sample of municipalities. In the Algarve region, the reform targeted certain municipalities and parishes and our data only has information at the parish level after 2003. We also excluded Odivelas, Trofa, and Vizela municipalities, because these were only founded in 1998. Our analysis does not include the municipalities of Madeira and Azores, as these autonomous regions have a different tax regime. After 2008, we exclude four municipalities (Abrantes, Constância, Coruche, and Sever do Vouga) as they moved from the control to the treated group.
}

treated municipalities based on: population density, income level, purchasing power, and social, economic, and cultural opportunities. Subsequently, in order to comply with EU legislation, the government identified the eligible municipalities in 2001.

Table 1 presents the summary statistics for the treated and control municipalities before the adoption of the reform. As expected, less-favoured municipalities were explicitly targeted for the tax reform. The inland municipalities were smaller in terms of purchasing power and population density.

Although the municipalities were not randomly selected to be eligible for the tax reform, discussions with municipality and tax officials suggested that the decision to select the inland municipalities was also driven by political reasons. The reform mainly targeted municipalities whose mayor were from the same party that proposed the bill. Only $47 \%$ of the treated municipalities were from the opposition party at the time of the reform.

Two features of the Portuguese taxation regime deserve additional discussion. First, as a measure to reduce the informal sector, in 2001, the government created a simplified taxation regime for self-employed individuals, with a tax rate of $20 \%$. Second, personal taxes were also subjected to several reforms. Note, however, that both these reforms applied to all individuals and municipalities in the country.

\section{Data and variables}

To implement our empirical analysis, we use municipaland individual-level data. Our municipal-level data comes from a matched employer-employee dataset, Quadros de Pessoal (QP). QP is based on a mandatory survey submitted annually to the Portuguese Ministry of Employment and Social Security by firms with at least one employee. The dataset covers virtually all employees and firms in the Portuguese private sector. From QP, we select all start-ups established in eligible industries $^{7}$ between January 1997 and December 2011. New entries created by mergers, takeovers, breakups, or changes in legal form or in the industry are not included. To reduce spin-offs of existing firms, we restrict our analysis to new firms which have only one establishment. Accordingly, we also exclude all non-profit startups. Next, we aggregate this firm-level data to

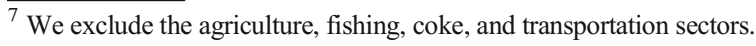


Fig. 1 Corporate Income Tax Rates. Notes: This figure separately plots the corporate income tax rates applicable to all municipalities in mainland Portugal for the period 20012011 for both treated and control municipalities. These rates do not apply to Madeira and the Azores islands

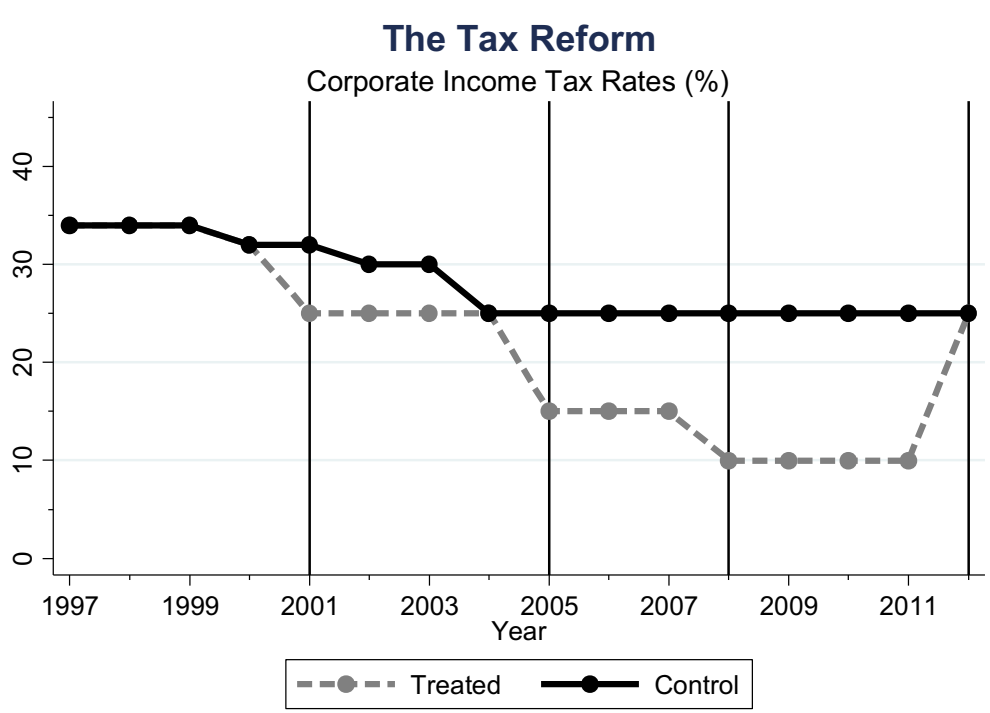

municipal-level data, to study the impact of the tax reform on firm entry and new firm job creation rates. Entry rate is measured by the number of entrants relative to the number of existing firms at the beginning of each year. We use a similar approach to compute new firm job creation rates by computing the number of jobs created by start-ups relative to the total workforce at the beginning of each year. ${ }^{8}$

Figure 3 plots the evolution of the average entry rates separately for the treated (inland) and control (coastal) municipalities located on the borderline of the municipalities impacted by the tax reform. Before the tax reform, the average yearly entry rate for inland and coastal municipalities was $2.30 \%$ and $2.22 \%$, respectively. The difference in means statistics for the pre-period was $0.08 \%$ ( $p$ value 0.188 ). However, after the reform, the difference in entry rates increases to $0.432 \%$ ( $p$ value 0.00 ). The positive effect on the entry rate prevails after the second (2005) and third (2008) revisions of the tax policy. Our graphical inspection does not seem to show an evolution which is capable of undermining the parallel trend's assumption. Nevertheless, this assumption will be explicitly tested with an event study.

We supplement these data with information from other sources. For example, municipality-level data regarding inhabitants, population density, and purchasing power are obtained from the National Statistics Office.

\footnotetext{
${ }^{8}$ Alternatively, we could have reported the labour market approach, standardizing the number of entrants with respect to the size of the work force (Audretsch and Fritsch 1994). Our results do not change when using this alternative approach.
}

The municipality elections data originate from the Portuguese National Elections Commission.

Table 2 presents the summary statistics regarding the characteristics of the municipalities. The sample contains 11,736 municipality-month observations. The average entry rate per month is $0.431 \%$, while new firm job creation is $0.287 \%$. Before 2001 , the average monthly entry rate for the treated and control municipalities was $0.358 \%$ and $0.398 \%$, respectively. After 2001, these numbers were $0.441 \%$ and $0.453 \%$, respectively. The majority of the entry rate is for start-ups with one to ten employees. The entry rate equals $0.22 \%, 0.18 \%$, $0.03 \%$, and $0.002 \%$ for start-up with $1-2,3-10,11-$ 50 , and more than 50 employees, respectively.

Our individual-level data also originate from QP. These data include a unique identifier which crossreferences individuals and firms, making it possible to match founders' characteristics with their start-ups' characteristics. For each individual, QP provides information regarding gender, age, date of hire, number of years of education, occupation, working hours, and earnings. For each start-up located in the borderline municipalities, we identify the founders and their background history. We restrict the sample to full-time entrepreneurs aged between 20 and 60, who transitioned to entrepreneurship up until 2009. ${ }^{9}$ The entrepreneur sample includes 20,023 founders, who established 14,578

\footnotetext{
${ }^{9}$ We restrict our sample to start-ups established up until 2009, to be able to compute three-year survival rates.
} 


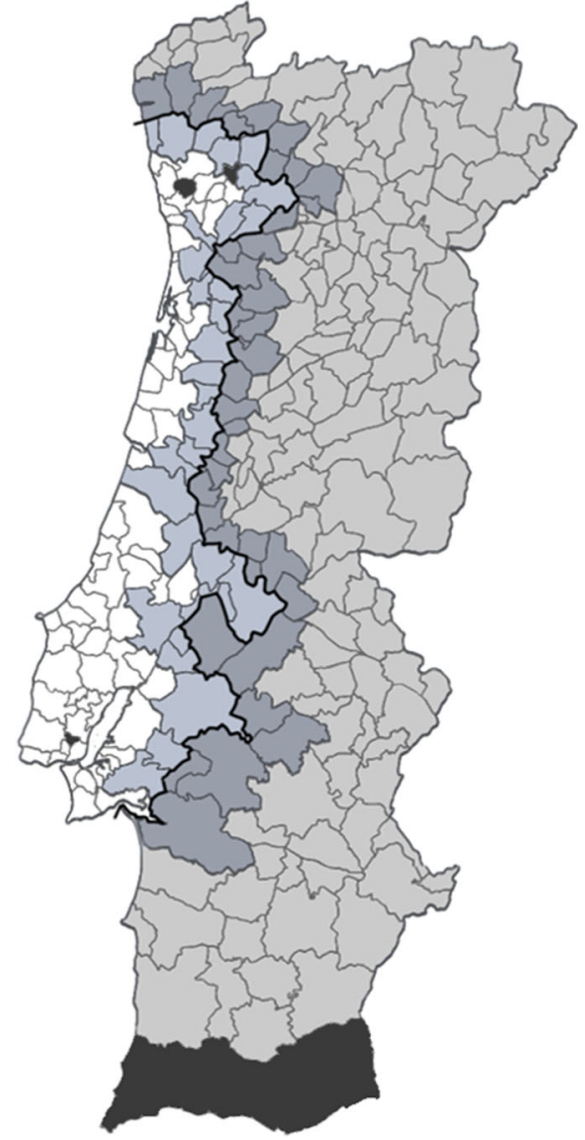

Fig. 2 Treated and Control Municipalities. Notes: This figure plots the treated and control municipalities which comprise the borderline municipalities. The borderline is defined by the thicker line. The map presents the treated group (inland), on the right-hand side and the control group (coastal), on the left-hand side. For this study, the control group comprises the municipalities in the coastal region marked in light grey and the treated group the municipalities in the inland region marked in dark grey. We mark the municipalities excluded from the analysis in black: all municipalities in the Algarve region, and Odivelas, Trofa, and Vizela municipalities

new firms, with a total of 142,608 entrepreneur-year observations. ${ }^{10}$ We use this sample to evaluate the impact of the tax reform on start-ups' performance.

Panels A and B of Table 3 present the descriptive statistics for the entrepreneur sample. Start-ups in our data are small and employ one employee, on average. After the first 3 years, approximately 3790 start-ups fail, which corresponds to a failure rate of $26 \%$. During the first years of these start-ups, the number of employees

\footnotetext{
${ }^{10}$ As QP data do not provide information regarding sales for all firms and years, the number of observations is reduced to 116,588 .
}

increases to six. The average age of the start-ups in our data is four and they generate more than $€ 50,000$ of sales per employee. Two-thirds of founders are aged between 20 and 40, 70\% are male, and $48 \%$ attended junior high school. In terms of experience, $22 \%$ of founders had worked in the same industry previously, $13 \%$ had held managerial positions, and $12 \%$ had started a venture beforehand.

Next, we select all individuals working in the eligible industries in the borderline municipalities in mainland Portugal between 1997 and 2009, within the age range of 20-60, and with known professional careers. To identify the founders, we merge the latter dataset with the entrepreneurs' sample. Panel C of Table 3 presents the descriptive statistics for the individuals' sample. There are 1,369,882 individuals in the estimation sample, of whom $1.5 \%$ became entrepreneurs. We have a total of 6,157,034 individual-year observations and 20,071 transitions to entrepreneurship $(0.33 \%)$. This allows us to compare the characteristics of the founders who were more likely to take advantage of the reform.

Appendix 2 provides additional details regarding the database and variable construction.

\section{Methodology and results}

\subsection{Municipal-level analyses: firm entry and job creation}

To estimate the effect of the tax reform on entrepreneurial outcomes - firm entry and job creation - we estimate the following difference-in-differences specification for municipality $i$, year $t$, and month $m$, for the period between 1997 and $2011^{11}$ :

$y_{i m t}=\theta_{i}+\alpha_{m}+\delta(t)+\lambda$ Treated $_{i} \times$ Post Period $_{i t}+X_{i t}^{\prime} \beta+\varepsilon_{\text {imt }}$

The dependent variables are the outcome variables entry rate and new firm job creation, as previously defined. Treated is a binary variable that equals one if the municipality reduced the corporate tax rate, and

\footnotetext{
${ }^{11}$ The tax reform was initially scheduled to enter into force in 2000, yet it was only effective 1 year later. Thus, we exclude the years 2000 and 2001 because of anticipation effects and unavailability of employee information, respectively. Our results do not change if we include the year 2000 .
} 
Table 1 Differences between the treatment and control group before the tax reform

\begin{tabular}{|c|c|c|c|c|}
\hline Variable & $N$ & Treated (inland) & Control (coastal) & Difference (inland - coastal) \\
\hline Entry rate $(\%)$ & 2556 & $\begin{array}{l}0.358 \\
(0.021)\end{array}$ & $\begin{array}{l}0.398 \\
(0.021)\end{array}$ & $\begin{array}{l}-0.040 * * \\
(0.030)\end{array}$ \\
\hline Birth job creation (\%) & 2556 & $\begin{array}{l}0.355 \\
(0.029)\end{array}$ & $\begin{array}{l}0.267 \\
(0.017)\end{array}$ & $\begin{array}{l}+0.088^{* * *} \\
(0.035)\end{array}$ \\
\hline Incumbent job creation (\%) & 2556 & $\begin{array}{l}0.040 \\
(0.016)\end{array}$ & $\begin{array}{l}0.045 \\
(0.010)\end{array}$ & $\begin{array}{l}-0.005 \\
(0.020)\end{array}$ \\
\hline Purchasing power & 2556 & $\begin{array}{l}0.050 \\
(0.000)\end{array}$ & $\begin{array}{l}0.068 \\
(0.000)\end{array}$ & $\begin{array}{l}-0.018^{* * *} \\
(0.001)\end{array}$ \\
\hline Population density & 2556 & $\begin{array}{l}5.005 \\
(0.020)\end{array}$ & $\begin{array}{l}6.025 \\
(0.024)\end{array}$ & $\begin{array}{l}-1.020^{* * *} \\
(0.031)\end{array}$ \\
\hline PSD party & 2556 & $\begin{array}{l}0.474 \\
(0.014)\end{array}$ & $\begin{array}{l}0.364 \\
(0.014)\end{array}$ & $\begin{array}{l}+0.110 * * * \\
(0.019)\end{array}$ \\
\hline
\end{tabular}

Data is measured by month and municipality for the period 1997-1999. Entry rate is the number of entrants relative to the number of existing firms at the beginning of each year. New firm and incumbent job creation is the number of jobs created by start-ups and incumbent firms relative to the workforce at the beginning of each year, respectively. PSD party is a dummy variable equaling one if the mayor belonged to the PSD party. The symbols ${ }^{*},{ }^{* *}$, and ${ }^{* * * *}$ represent significance levels of $10 \%, 5 \%$, and $1 \%$, respectively. The symbols presented are for a one-tailed test

zero otherwise. Post Period is an indicator variable that equals one for the period between 2001 and 2011. $X$ is a vector of the following sociodemographic factors: purchasing power to control for economic activity at the municipality level, and population density to control for population factors. $\alpha_{m}$ are monthly dummy variables to control for seasonal effects, $\theta_{i}$ are municipality fixed effects, and $\delta(t)$ is a polynomial-time trend. The standard errors for this and all subsequent estimations are clustered at the municipality level (Bertrand et al. 2004). The coefficient of interest in Eq. (1) is $\lambda$, which measures the difference in firm formation and job creation between the treated and control municipalities.

There are three main challenges when assessing the causal impact of taxes on entrepreneurship. First, entrepreneurs choose from among a large number of heterogeneous locations to establish their ventures. Many of
Fig. 3 Average Yearly Entry Rates. Notes: The figure separately plots the average yearly entry rates for the period between 1997 and 2012 for the treated (inland) and control (coastal) municipalities. The vertical lines represent the various revisions of the tax reform. Note that the benefits for inlandness were eliminated in 2012

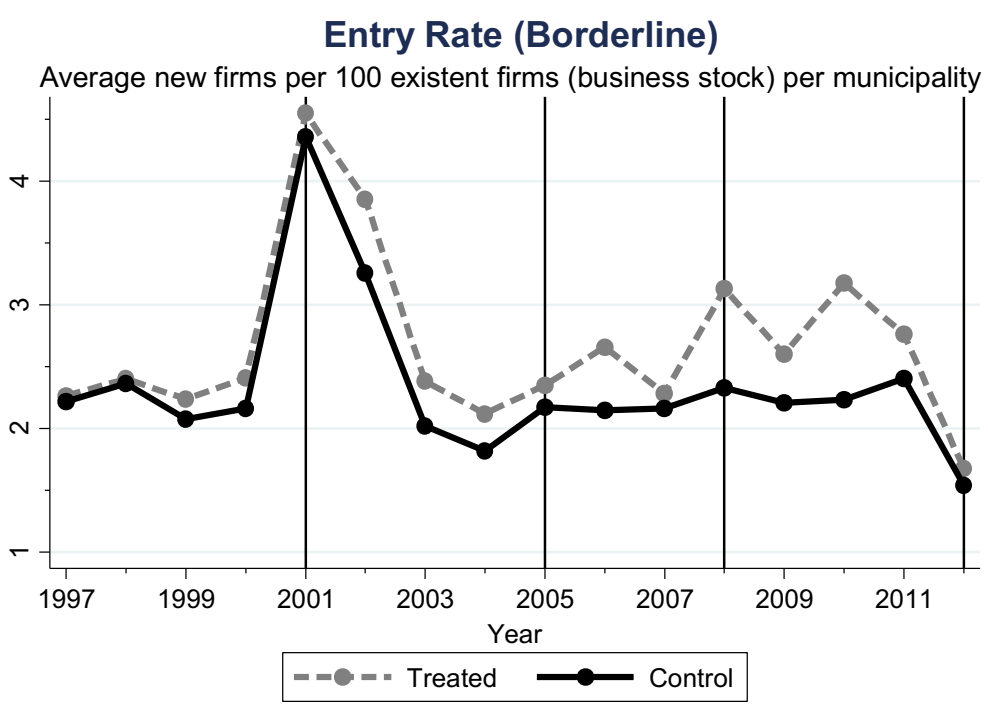


Table 2 Descriptive statistics for the municipality level analysis

\begin{tabular}{llll}
\hline Variable & $N$ & Mean & Std. dev. \\
\hline Entry rate (\%) & 11,736 & 0.431 & 0.845 \\
Birth job creation (\%) & 11,736 & 0.287 & 0.759 \\
Incumbent job creation (\%) & 11,736 & 0.037 & 0.423 \\
Treated × post period & 11,736 & 0.427 & 0.495 \\
Purchasing power & 11,736 & 0.067 & 0.018 \\
Population density & 11,736 & 5.485 & 0.965 \\
PSD party & 11,736 & 0.429 & 0.495 \\
\hline
\end{tabular}

Data is measured by month and municipality for the period 19972011 , excluding 2000. Treated is a dummy variable, equaling one if the start-up is established in an inland borderline municipality, and zero otherwise. Post period is a dummy variable, equaling one from 2001 onwards, and zero otherwise

the characteristics of these locations are unobserved. To mitigate this issue, we control for the municipallevel characteristics and evaluate municipalities on the borderline. In principle, the control municipalities are more similar to the treated ones. Second, unique features of the tax system may be endogenous to firm entry, which could lead to reverse causality. We circumvent these concerns by taking advantage of a quasi-natural experiment and by adopting an instrumental variable approach. Finally, to measure the impact of the tax reform, we need a counterfactual hypothesis of what firm entry and job creation would have been like in the treated municipalities if the tax reform had not occurred. To this end, we select a set of control municipalities which we expect would be a viable representation of the performance of the treated municipalities if there had been no tax reform. More specifically, we assume that the tax reform was not introduced in a way that correlates with unobserved trends in the dependent variable. To investigate this concern, we analyse the determinants of the tax reform adoption. Table 4 presents the probit results for the period 1997-1999 (before the tax reform). We include a municipality mayor dummy (PSD party) to account for the fact that the tax reform was implemented after the 1997 municipal election, and also that the tax reform bill was proposed by the main opposition party. As time-varying economic variables, we include population density and purchasing power. The omitted categories include municipalities whose
Table 3 Descriptive statistics for the entrepreneurs and individual sample

\begin{tabular}{|c|c|c|c|}
\hline & $N$ & Mean & Std. dev. \\
\hline \multicolumn{4}{|l|}{ Panel A: Start-up level } \\
\hline Sales per employee & 116,588 & 51,245 & 185,268 \\
\hline Employees & 142,608 & 6.06 & 11.57 \\
\hline Firm age & 142,608 & 4.13 & 3.27 \\
\hline Survival & 14,578 & 0.74 & 0.44 \\
\hline Initial size & 14,578 & 1.08 & 0.81 \\
\hline Founders & 14,578 & 1.01 & 0.11 \\
\hline \multicolumn{4}{|l|}{ Panel B: Founder level } \\
\hline Gender (male) & 20,023 & 0.70 & 0.46 \\
\hline Age $20-29$ & 20,023 & 0.27 & 0.45 \\
\hline Age $30-39$ & 20,023 & 0.39 & 0.49 \\
\hline Age $40-49$ & 20,023 & 0.24 & 0.43 \\
\hline Age $50-60$ & 20,023 & 0.09 & 0.29 \\
\hline Very low education & 20,023 & 0.22 & 0.42 \\
\hline Low education & 20,023 & 0.48 & 0.50 \\
\hline Medium education & 20,023 & 0.18 & 0.38 \\
\hline High education & 20,023 & 0.11 & 0.32 \\
\hline Foreign & 20,023 & 0.01 & 0.10 \\
\hline Industry experience & 20,023 & 0.22 & 0.42 \\
\hline Managerial experience & 20,023 & 0.13 & 0.33 \\
\hline Entrepreneurial experience & 20,023 & 0.12 & 0.32 \\
\hline \multicolumn{4}{|l|}{ Panel C: Individual level } \\
\hline Transition to entrepreneurship & $6,157,034$ & 0.003 & 0.06 \\
\hline Gender (male) & $6,157,034$ & 0.58 & 0.49 \\
\hline Age $20-29$ & $6,157,034$ & 0.27 & 0.44 \\
\hline Age $30-39$ & $6,157,034$ & 0.34 & 0.47 \\
\hline Age $40-49$ & $6,157,034$ & 0.25 & 0.43 \\
\hline Age $50-60$ & $6,157,034$ & 0.14 & 0.35 \\
\hline Very low education & $6,157,034$ & 0.33 & 0.47 \\
\hline Low education & $6,157,034$ & 0.46 & 0.50 \\
\hline Medium education & $6,157,034$ & 0.13 & 0.34 \\
\hline High education & $6,157,034$ & 0.07 & 0.26 \\
\hline Foreign & $6,157,034$ & 0.02 & 0.13 \\
\hline
\end{tabular}

Panels A and B present the descriptive statistics for the entrepreneurs' sample and panel $\mathrm{C}$ are the descriptive statistics for the entrepreneurs' and employees' sample (individual sample). The entrepreneurs' sample includes 20,023 founders, who established 14,578 new firms and a total of 142,608 entrepreneur-year observations. As QP data do not provide information on sales for all firms and years, the number of observations reduces to 116,588 . In panel C, we evaluate 6,157,034 individual-year observations. All variables (except for sales per employee, employees, firm age, and transition to entrepreneurship) are not time varying, and hence, they do not take a different value for each year. The definition of the variables is summarized in Appendix 3, Table 10 
mayors belonged to other political parties, including coalitions. $^{12}$

Municipalities whose mayors belonged to the party that proposed the bill (PSD party) were significantly more likely to be eligible for the tax reform. This suggests that the mayors might have recommended the party to propose the tax reform bill in parliament. As expected, the economic time-varying covariates are significant and are relevant economically. High income and density populated municipalities are less likely to be eligible for the tax reform.

Column (1) of panel A of Table 5 presents the estimated coefficient for firm entry using OLS estimation for Eq. (1). To account for possible endogeneity issues, column (2) presents the results using the instrumental variable (IV) estimation. We instrument the Treated variable using a dummy variable that equals one if the mayor belonged to PSD party. ${ }^{13}$ The estimates for $\lambda$ are positive and statistically significant at the $1 \%$ level in column (1) and at the $10 \%$ level in column (2). The effect reported is of sizeable magnitude. Using the point estimates of column (2), we find that municipalities that reduced the corporate tax exhibited a 41 percentage points increase on firm entry. Considering that, before the reform, the average monthly entry rate in treated municipalities was $0.358 \%$ (Table 1), our point estimates correspond to a substantial increase in firm entry. Back-of-the-envelope calculations suggest that over the first 3 years, the impact at the national level would be approximately 29,150 new firms. ${ }^{14}$

Another important issue concerns the validity of our instrument. For an instrument to be valid, two conditions have to be satisfied: i) the political party of the mayor that proposed the policy (PSD party) has to be correlated with the tax reform adoption, and, ii) the instrument has to be uncorrelated with the error term. The former condition is satisfied (see the reduced form in Appendix 3, Table 11). For the second condition, we assumed that the political ideology of the mayor influences the fiscal policies

\footnotetext{
${ }^{12}$ The main political parties in Portugal are: PS - Partido Socialista (centre-left and the governing party at the time); PSD - Partido Social Democrata (centre-right), PCP-Partido Comunista Português (communist, left-wing); CDS - Centro Democrático Social (Christian-democrats, right-wing). Right-wing coalitions are mostly formed by the PSD or CDS with a smaller party).

${ }^{13} \mathrm{Da}$ Rin et al. (2011) also use political variables to evaluate the effect of taxation on firm creation.

${ }^{14}$ Our approximation assumes 0.41 entry rate $\times$ average 960 incumbent firms per municipality $/ 100 \times 278$ municipalities $\times 36$ months $\times$ an average survival rate of 0.74 (which is corroborated by the fact that we estimate a 36-month survival rate of 0.90 for start-ups established after the reform).
}

Table 4 Tax reform adoption in eligible municipalities

\begin{tabular}{ll}
\hline Probit (treated) & $(1)$ \\
\hline PSD party & $0.503 * * *$ \\
& $(0.065)$ \\
Purchasing power & $-41.793 * * *$ \\
& $(2.653)$ \\
Population density & $-0.889 * * *$ \\
& $(0.047)$ \\
Observations & 2556 \\
Pseudo $R$-squared & 0.391 \\
\hline
\end{tabular}

Data is measured by month and municipality for the period 19971999. The model includes month fixed effects and quadratic time trend. The symbols $*$, **, and $* * *$ represent significance levels of $10 \%, 5 \%$, and $1 \%$, respectively

without directly affecting the entrepreneur's decision to start and grow a business. To check if the instrumental variable (PSD party) was not correlated with firm entry and job creation, we regressed it on firm entry and birth job creation. The results are presented in Appendix 3, Table 12. We find that the political dummy was not correlated with trends in firm and job creation before the tax reform. Nonetheless, one could argue that the PSD party, being a liberal-conservative party, might be more lenient towards entrepreneurial activity. Indeed, the PSD party is more to the right and the PS party to the left; however, both parties are situated in the centre of the political spectrum. To test this concern, we run our baseline specification by excluding the municipalities whose mayors used to belong to the PS party but changed to the PSD party. Our main results remain statistically significant (Appendix 3, Table 13). Lastly, the weak identification test is rejected with Kleibergen-Paap F-statistics above the cut-off level of $10 \%$ in all estimations.

Column (3) evaluates the different revisions of the tax reform. We substitute the Post Period variable with three binary variables for the following different time periods: $T 1$, for the period 2001-2004; T2 for 20052007, and; T3 for 2008-2011. In the first, second and third periods, the entry rate increased by 38,22 , and 32 percentage points, respectively. The effect is larger and only significant in the first period.

The identification strategy of our baseline results relies on two assumptions: (i) the municipality characteristics must be balanced in the treatment and control groups, and (ii) the municipalities must show similar parallel trends in the pre-treatment period. With respect to the first requirement, we solve this by using an IV 
Table 5 The impact of the tax reform on entry and birth job creation

\begin{tabular}{|c|c|c|c|c|c|}
\hline & \multirow{2}{*}{$\frac{\text { OLS }}{\text { (1) Policy }}$} & \multicolumn{4}{|c|}{ Instrumental variable (IV) estimations } \\
\hline & & (2) Policy & (3) Policy per period & (4) Placebo & (5) After the end of the policy \\
\hline \multicolumn{6}{|l|}{ Panel A: Entry rate } \\
\hline Treated $\times$ post period & $\begin{array}{l}0.181^{\text {**** }} \\
(0.031)\end{array}$ & $\begin{array}{l}0.411^{*} \\
(0.214)\end{array}$ & & $\begin{array}{l}-0.042 \\
(0.083)\end{array}$ & $\begin{array}{l}-0.504^{* * *} \\
(0.111)\end{array}$ \\
\hline Treated $\times \mathrm{T} 1$ & & & $\begin{array}{l}0.378^{* * *} \\
(0.181)\end{array}$ & & \\
\hline Treated $\times \mathrm{T} 2$ & & & $\begin{array}{l}0.219 \\
(0.245)\end{array}$ & & \\
\hline Treated $\times \mathrm{T} 3$ & & & $\begin{array}{l}0.321 \\
(0.311)\end{array}$ & & \\
\hline Purchasing power & $\begin{array}{l}-0.742 \\
(1.497)\end{array}$ & $\begin{array}{c}-0.578 \\
(1.657)\end{array}$ & $\begin{array}{l}0.569 \\
(1.949)\end{array}$ & $\begin{array}{l}3.626 \\
(3.257)\end{array}$ & $\begin{array}{l}1.583 \\
(1.717)\end{array}$ \\
\hline Population density & $\begin{array}{l}0.610^{* * * *} \\
(0.174)\end{array}$ & $\begin{array}{l}1.116^{* *} \\
(0.531)\end{array}$ & $\begin{array}{l}0.808 \\
(0.795)\end{array}$ & $\begin{array}{c}-0.292 \\
(0.697)\end{array}$ & $\begin{array}{l}-0.297 \\
(0.303)\end{array}$ \\
\hline Time range & $1997-2011$ & 1997-2011 & $1997-2011$ & 1994-1999 & $2001-2012$ \\
\hline Treatment effect & $2001-2011$ & $2001-2011$ & $2001-2011$ & 1997-1999 & 2012 \\
\hline Observations & 11,736 & 11,736 & 11,736 & 5,112 & 9,850 \\
\hline Adjusted $R$-squared & 0.636 & 0.632 & 0.634 & 0.663 & 0.603 \\
\hline Kleibergen-Paap $F$-statistics & & 228.7 & 41.1 & 464.4 & 203.0 \\
\hline \multicolumn{6}{|l|}{ Panel B: Birth job creation } \\
\hline Treated $\times$ post period & $\begin{array}{l}0.103^{* * * *} \\
(0.034)\end{array}$ & $\begin{array}{l}0.236 \\
(0.196)\end{array}$ & & $\begin{array}{l}0.030 \\
(0.115)\end{array}$ & $\begin{array}{l}-0.300^{* * * *} \\
(0.082)\end{array}$ \\
\hline Treated $\times \mathrm{T} 1$ & & & $\begin{array}{l}0.220 \\
(0.186)\end{array}$ & & \\
\hline Treated $\times \mathrm{T} 2$ & & & $\begin{array}{l}0.150 \\
(0.285)\end{array}$ & & \\
\hline Treated $\times \mathrm{T} 3$ & & & $\begin{array}{l}0.205 \\
(0.374)\end{array}$ & & \\
\hline Purchasing power & $\begin{array}{l}-3.002^{* *} \\
(1.214)\end{array}$ & $\begin{array}{l}-2.907^{* *} \\
(1.359)\end{array}$ & $\begin{array}{l}-2.430 \\
(1.807)\end{array}$ & $\begin{array}{l}1.045 \\
(4.016)\end{array}$ & $\begin{array}{l}-1.458 \\
(1.478)\end{array}$ \\
\hline Population density & $\begin{array}{l}0.460^{* *} \\
(0.182)\end{array}$ & $\begin{array}{l}0.753 \\
(0.517)\end{array}$ & $\begin{array}{l}0.637 \\
(0.999)\end{array}$ & $\begin{array}{l}0.041 \\
(0.775)\end{array}$ & $\begin{array}{l}-0.125 \\
(0.285)\end{array}$ \\
\hline Time range & $1997-2011$ & 1997-2011 & $1997-2011$ & 1994-1999 & $2001-2012$ \\
\hline Treatment effect & $2001-2011$ & $2001-2011$ & 2001-2011 & 1997-1999 & 2012 \\
\hline$N$ observations & 11,736 & 11,736 & 11,736 & 5,112 & 9,850 \\
\hline Adjusted $R$-squared & 0.375 & 0.374 & 0.374 & 0.339 & 0.382 \\
\hline Kleibergen-Paap $F$-statistics & & 228.7 & 41.1 & 464.4 & 203.0 \\
\hline
\end{tabular}

Data is measured by month and municipality for the periods 1997-2011 in columns (1) to (3), for 1994-1999 in column (4), and for 20012012 in column (5). All models include municipality and monthly fixed effects and a quadratic time trend. The symbols *, $* *$, and $* * *$ represent significance levels of $10 \%, 5 \%$, and $1 \%$, respectively

approach and by including several municipality socioeconomic variables. Regarding the second assumption, we performed three exercises. First, we compare the evolution of firm entry in treated and control municipalities during the pre-treatment and treatment periods (Angrist and Pischke 2009). Figure 3 does not provide evidence of distinct pre-treatment trends between treatment and control municipalities which are 
capable of undermining our identification strategy. Second, we implement an event study design by estimating the following variation of our baseline regression:

$$
\begin{aligned}
y_{i t}= & \theta_{i}+\delta(t)+\sum_{l=1997}^{2011} \omega_{l} \text { Treated }_{i} \times \text { Post Period }_{i t} \\
& +X^{\prime}{ }_{i t} \beta+\varepsilon_{i t}
\end{aligned}
$$

where $\omega_{l}$ is a set of indicator variables for the 3 years prior to the tax reform and the 11 years after the tax reform. Our omitted indicator is $\omega_{2000}$. Figure 4 plots the $\omega_{l}$ coefficients. The coefficients on the "lags" are generally close to zero. Using the F test, we cannot reject the hypotheses that $\omega_{1997}, \ldots, \omega_{1999}=0$, which suggests that, on average, during the years prior to the tax reform there was no unusual trend in firm entry. It is only from 2001 onwards that the interaction terms become significantly positive. Our $F$ test easily rejects the null hypothesis that these coefficients jointly equal zero. The results imply that in the first year after the corporate tax rate reduction, there is a statistically significant difference in entry rates between treated and control municipalities. Finally, we perform a falsification (placebo) test by restricting the period of analysis to 1994-1999. The treatment and control groups remain the same; however, the Post Period variable equals one for the period between 1997 and 1999. The results are presented in column (4) of Table 5. This exercise displays no statistically significant effects. Consequently, all these tests strengthen the interpretation that the results are caused by the specific timing and scope of the tax reform.

In 2012, the tax benefits were abolished. Column (5) presents the IV results for the period between 2001 and 2012, and the Post Period variable is set to one for the year 2012, as opposed to column (2), where the variable equaled one for the period between 2001 and 2011. The negative and statistically significant coefficient confirms our previous understanding that a reduction in corporate taxes increases firm entry in eligible municipalities.

In panel B of Table 5, we run the same specifications to examine the impact of the tax reform on new firm job creation. After controlling for potential endogeneity, the coefficients in column (2) suggest that those municipalities which reduced their corporate tax rate exhibited a 24 percentage points increase in new firm job creation per month, corresponding to 223,500 jobs created by start-ups over the first years of activity at the national level. ${ }^{15}$

\footnotetext{
${ }^{15}$ For our new firm jobs estimate, we take a 0.24 new firm job creation rate $\times$ average 9460 employees per municipality $\times 278$ municipalities $\times$ 36 months / 100 .
}

We expect that the effect of the tax reform on firm entry should be found in high-quality firms, more specifically in slightly larger and more-productive ventures. Accordingly, we estimate our baseline Eq. (1) for entry rate, but having been categorized by start-up's initial size. Columns (1) to (4) of panel A of Table 6 report the coefficients using IV estimations for the entry rate of start-ups with 1-2, 3-10, 11-50, and more than 50 employees. Our estimates indicate a statistically significant increase in the entry rate of start-ups with 3-10 employees.

Next, the entry rate is broken down into five sectors: manufacturing, construction, wholesale and retail trade, services, and other industries. Panel B of Table 6 presents the results of this analysis, again using Eq. (1). The estimated positive impact of the tax reform operates in the construction and trade sectors. To further investigate the impact of the tax reform, we split our sample into knowledge and non-knowledge-based industries and according to firms' level of technology. According to the OECD (2002), technology-based industries can be divided into high and medium-high technology industries, and medium-low and low technology industries. Our results depicted in Appendix 3, Table 14 suggest a positive and significant effect of the tax reform on nonknowledge-based industries. Focusing on the manufacturing sector, we find a positive but nonsignificant effect of the tax reform in the textile, clothing and footwear products, and basic metals. Note that Portugal is a service-oriented economy; therefore, the positive effect of the reform on non-knowledge industries is justified by the importance of those industries in the Portuguese economy. Additionally, these industries are subjected to lower barriers to entry.

\subsection{Entrepreneurs-level analysis: survival and productivity}

Using the entrepreneurs' sample, we evaluate the performance of the start-ups that took advantage of the tax reform by estimating:

$$
\begin{aligned}
y_{\text {jimt }}= & \theta_{i}+\alpha_{m}+\delta(t)+\lambda \text { Treated }_{i} \times{\text { Post } \text { Period }_{i t}}^{\prime} \\
& +X^{\prime}{ }_{i t} \beta+W_{j}^{\prime} \vartheta+\epsilon_{\text {jimt }}
\end{aligned}
$$

where $j$ denotes the founder.

The dependent variables are start-ups' survival and productivity. Survival is an indicator variable which equals one for start-ups that survived the first 3 years, and zero otherwise. Productivity is measured as the logarithm of 
Fig. 4 Event Study. Notes. This figure plots the coefficients $\omega_{l}$ from Eq. (2). The dependent variable is the yearly entry rate. Vertical lines are the $95 \%$ confidence intervals for the coefficients. The $F$-statistic for pre-period is $1.87(p=0.143)$ and the $F$ test statistic for post period is $17.74(p<0.001)$

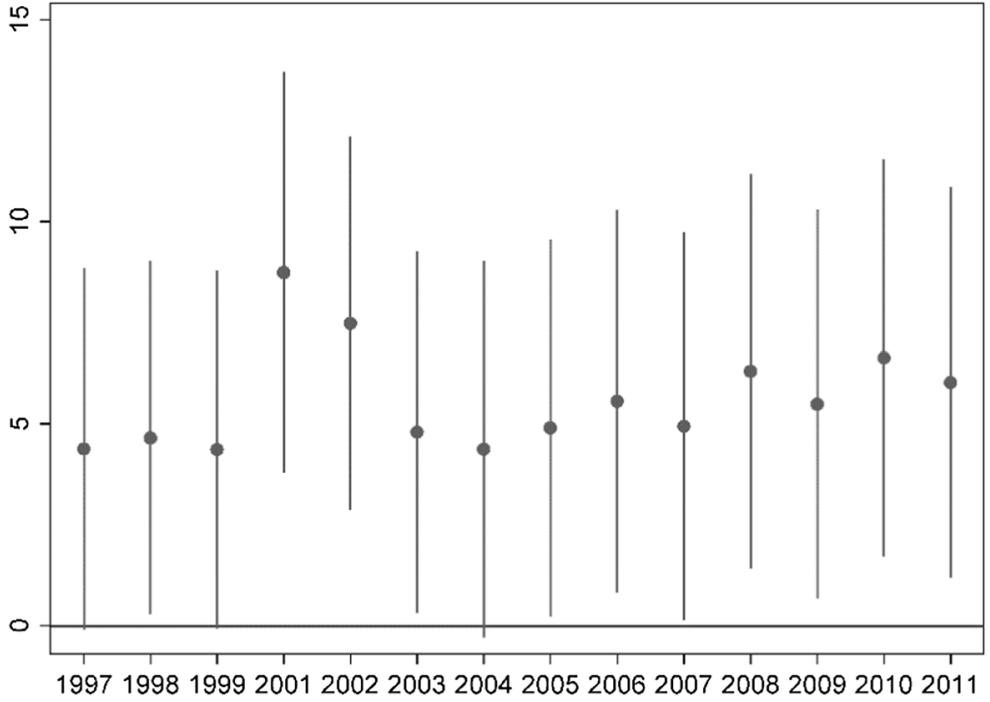

initial sales divided by the initial number of employees (with sales expressed in 2011 values, in Euros). Again, our variable of interest is $\lambda$ and we include municipality $\left(\theta_{i}\right)$ and month $\left(\alpha_{m}\right)$ fixed effects, the quadratic time trend $(\delta(t))$, as well as additional control variables $\left(X_{i t}\right)$. We also include a vector for founder characteristics $\left(W_{j}\right)$ : gender; four indicator variables for the founder's age, partitioned at 20, 30, 40, and 50; an "industry experience" variable; "managerial experience"; foreign founders; an "entrepreneurial experience" variable; and, education (see Table 10 in Appendix 3). In reporting the estimated coefficients, our omitted categories are founders aged 20-29, with "very low education".

Columns (1) and (2) of Table 7 present the estimates for a three-year survival for the full sample of entrepreneurs using the IV estimation. ${ }^{16}$ In the first column, we include our control variables. In line with previous studies on survival, the control variables are in the same direction as those expected according to the previous literature. Survival is higher for larger firms founded by well-educated, male, and relatively older individuals who have experience in the industry. Column (2) adds the interaction variable of interest: Treated $_{i} \times$ Post Period $_{i t}$. The positive coefficient indicates that startups formed after the tax reform are approximately 37

\footnotetext{
${ }^{16}$ The probability of survival is not extreme, therefore the linear probability and the IV models fit well in our data and offer a straightforward interpretation (Hellevik 2007). Nevertheless, our results do not change if we use Probit and IV Probit alternative estimation procedures (see Appendix 3, Table 19).
}

percentage points more likely to survive. Appendix 3, Table 15, presents the reduced form.

Columns (4) and (5) of Table 7 present the results for sales per employee. Our results suggest that the introduction of the tax reform is associated with an increase in sales per employee. Similar to the survival analysis, male, better-educated individuals with industry experience are associated with higher levels of productivity. Conversely, entrepreneurial experience appears to be a disadvantage with regard to productivity. Nevertheless, this result is in line with previous studies that suggest the absence of entrepreneurial learning for serial entrepreneurs (Eggers and Song 2014) and attributes their success to their inherent quality (Gompers et al. 2010) or selection (Chen 2013; Rocha et al. 2015).

\subsection{Individual-level analysis: entrepreneur characteristics}

Next, using the individual sample, we examine the demographic characteristics of the founders who were introduced to the market on account of the tax reform by estimating:

$$
\begin{aligned}
E_{j i t}= & \theta_{i}+\delta(t)+\lambda \text { Treated }_{i} \times \text { Post }_{\text {Period }} \text { it } \\
& +X^{\prime}{ }_{i t} \beta+W_{j}^{\prime} \vartheta+\epsilon_{i m t}
\end{aligned}
$$

where $j$ is the individual.

The dependent variable is an indicator variable which equals 1 if an individual $j$ transitions to entrepreneurship and establishes a start-up in municipality $i$ and year $t$, 
Table 6 The impact of the tax reform on firm entry by firm size and industry

\begin{tabular}{|c|c|c|c|c|c|}
\hline & $\begin{array}{l}\text { (1) } 1-2 \\
\text { employees }\end{array}$ & $\begin{array}{l}\text { (2) } 3-10 \\
\text { employees }\end{array}$ & (3) 11-50 employees & $\begin{array}{l}\text { (4) More than } 50 \\
\text { employees }\end{array}$ & \\
\hline \multicolumn{6}{|c|}{ Panel A: Effect on entry rate by size } \\
\hline \multirow[t]{2}{*}{ Treated $\times$ Post Period } & 0.110 & $0.240^{*}$ & 0.058 & 0.003 & \\
\hline & $(0.074)$ & $(0.136)$ & $(0.044)$ & $(0.003)$ & \\
\hline N Observations & 11,736 & 11,736 & 11,736 & 11,736 & \\
\hline Adjusted $R$-squared & 0.525 & 0.493 & 0.161 & 0.033 & \\
\hline \multirow[t]{2}{*}{ Kleibergen-Paap F-statistics } & 228.7 & 228.7 & 228.7 & 228.7 & \\
\hline & (1) Manufacturing & (2) Construction & (3) Trade (Retail and Wholesale) & (4) Services & (5) Other Industries \\
\hline \multicolumn{6}{|c|}{ Panel B: Effect on entry rate by industry } \\
\hline \multirow[t]{2}{*}{ Treated $\times$ post period } & 0.038 & $0.222^{* *}$ & $0.121^{*}$ & 0.017 & 0.013 \\
\hline & $(0.048)$ & $(0.105)$ & $(0.072)$ & $(0.031)$ & $(0.021)$ \\
\hline$N$ observations & 11,736 & 11,736 & 11,736 & 11,736 & 11,736 \\
\hline Adjusted $R$-squared & 0.314 & 0.305 & 0.460 & 0.378 & 0.264 \\
\hline Kleibergen-Paap $F$-statistics & 228.7 & 228.7 & 228.7 & 228.7 & 228.7 \\
\hline
\end{tabular}

Data is measured by month and municipality for the period 1997-2011. All models include municipality and month fixed effects and a quadratic time trend. The symbols $* * *$, and $* * *$ represent significance levels of $10 \%, 5 \%$, and $1 \%$, respectively

and 0 if that individual does not become an entrepreneur. Once again, we include municipality fixed effects $\left(\theta_{i}\right)$, the quadratic time trend, a vector of control variables $X_{i t}$, and a vector of individual characteristics $W_{j}$. The estimates for this specification using the IV method, are presented in Table $8 .{ }^{17}$

Not surprisingly, we show that the tax reform is associated with an increase in the probability of an individual becoming an entrepreneur. It should be noted, however, that only a small fraction of the individuals became entrepreneurs per year $(0.3 \%)$. Therefore, the tax reform is associated with a large increase in the decision to become an entrepreneur. As for the demographic and education variables, we can infer that male, older, and better-educated individuals are relatively more likely to transition to entrepreneurship. To account for the opportunity cost of transition to entrepreneurship, we control for the logarithm of hourly wage in column (3). ${ }^{18}$ The point estimate drops to 0.16 ; however, it continues to be statistically significant.

\footnotetext{
${ }^{17}$ As a robustness check, we compute Probit and IV Probit alternative estimation procedures (see Appendix 3, Table 20). Our results remain the same.

${ }^{18}$ Hourly wage is computed as being the monthly base wage and regular subsidies divided by monthly hours of work in the previous year. The hourly wage is quoted in 2011 Euros. Note that QP does not disclose wage information for the entrepreneurs.
}

To evaluate which type of individual is more likely to take advantage of the tax reform, we interact each of the demographic and educational variables with our indicator for the tax reform $\left(\right.$ Treated $_{i} \times$ Post Period $\left._{i t}\right)$ and add these interactions to Eq. (4). For each interaction, we constructed an instrument. Once again, the Treated variable is instrumented with a dummy variable equaling one if the mayor belonged to PSD party. The estimates are reported in column (2) of Table 8 . After the tax-reform, the probability of transitioning to entrepreneurship increases for bettereducated individuals (low, medium and high-educated individuals) in relation to very low-educated individuals (omitted category). Similarly, the fraction of female and older entrepreneurs (age 30-60) also increases in comparison to male and younger individuals, respectively. In contrast, the fraction of foreign entrepreneurs decreases relative to the omiited category (Portuguese individuals).

A potential concern is that the tax reform might have led to existing active unregistered/informal firms becoming formal. Following up on this observation, we estimated the impact of the tax reform on novice entrepreneurs, i.e., individuals who worked as paid employees before their transition to entrepreneurship. The results are presented in columns (3) and (4) of Table 8. We find that half of the new firms created were established by these "novice entrepreneurs". Nevertheless, some of these could also be existing firms 
Table 7 The impact of the tax reform on the performance of start-ups

\begin{tabular}{|c|c|c|c|c|c|}
\hline & \multicolumn{3}{|l|}{ Survival } & \multirow{2}{*}{\multicolumn{2}{|c|}{$\frac{\text { Productivity }}{\text { All entrepreneurs }}$}} \\
\hline & \multicolumn{2}{|c|}{ All entrepreneurs } & \multirow{2}{*}{$\begin{array}{l}\text { Novice entrepreneurs } \\
\text { (3) } \\
\text { IV }\end{array}$} & & \\
\hline & $\begin{array}{l}\text { (1) } \\
\text { OLS }\end{array}$ & $\begin{array}{l}(2) \\
\text { IV }\end{array}$ & & $\begin{array}{l}\text { (4) } \\
\text { OLS }\end{array}$ & $\begin{array}{l}(5) \\
\text { IV }\end{array}$ \\
\hline Treated $\times$ post period & & $\begin{array}{l}0.370 * * * \\
(0.138)\end{array}$ & $\begin{array}{l}0.489 * * \\
(0.244)\end{array}$ & & $\begin{array}{l}1.013 * * \\
(0.486)\end{array}$ \\
\hline Firm age & & & & $\begin{array}{l}1.457 * * * \\
(0.017)\end{array}$ & $\begin{array}{l}1.439 * * * \\
(0.019)\end{array}$ \\
\hline Initial size & $\begin{array}{l}0.040 * * * \\
(0.004)\end{array}$ & $\begin{array}{l}0.040 * * * \\
(0.004)\end{array}$ & $\begin{array}{l}0.042 * * * \\
(0.005)\end{array}$ & & \\
\hline Number founders & $\begin{array}{l}0.009 * * \\
(0.004)\end{array}$ & $\begin{array}{l}0.008 * \\
(0.004)\end{array}$ & $\begin{array}{l}-0.001 \\
(0.006)\end{array}$ & $\begin{array}{l}0.033 * * * \\
(0.011)\end{array}$ & $\begin{array}{l}0.032 * * * \\
(0.011)\end{array}$ \\
\hline Gender (male) & $\begin{array}{l}0.020 * * * \\
(0.006)\end{array}$ & $\begin{array}{l}0.021 * * * \\
(0.006)\end{array}$ & $\begin{array}{l}0.021 * * \\
(0.009)\end{array}$ & $\begin{array}{l}0.074 * * * \\
(0.018)\end{array}$ & $\begin{array}{l}0.073 * * * \\
(0.018)\end{array}$ \\
\hline Age $30-39$ & $\begin{array}{l}0.026 * * * \\
(0.007)\end{array}$ & $\begin{array}{l}0.025 * * * \\
(0.007)\end{array}$ & $\begin{array}{l}0.022 * * \\
(0.009)\end{array}$ & $\begin{array}{l}0.107 * * * \\
(0.019)\end{array}$ & $\begin{array}{l}0.108 * * * \\
(0.019)\end{array}$ \\
\hline Age $40-49$ & $\begin{array}{l}0.032 * * * \\
(0.008)\end{array}$ & $\begin{array}{l}0.031 * * * \\
(0.008)\end{array}$ & $\begin{array}{l}0.023 * * \\
(0.011)\end{array}$ & $\begin{array}{l}-0.002 \\
(0.023)\end{array}$ & $\begin{array}{l}-0.002 \\
(0.023)\end{array}$ \\
\hline Age $50-60$ & $\begin{array}{l}0.036 * * * \\
(0.010)\end{array}$ & $\begin{array}{l}0.033 * * * \\
(0.010)\end{array}$ & $\begin{array}{l}0.020 \\
(0.016)\end{array}$ & $\begin{array}{l}0.035 \\
(0.031)\end{array}$ & $\begin{array}{l}0.035 \\
(0.031)\end{array}$ \\
\hline Low educated & $\begin{array}{l}-0.003 \\
(0.007)\end{array}$ & $\begin{array}{l}-0.002 \\
(0.007)\end{array}$ & $\begin{array}{l}0.008 \\
(0.010)\end{array}$ & $\begin{array}{l}0.071 * * * \\
(0.018)\end{array}$ & $\begin{array}{l}0.070 * * * \\
(0.018)\end{array}$ \\
\hline Medium educated & $\begin{array}{l}0.012 \\
(0.009)\end{array}$ & $\begin{array}{l}0.014 \\
(0.009)\end{array}$ & $\begin{array}{l}0.029 * * \\
(0.013)\end{array}$ & $\begin{array}{l}0.093 * * * \\
(0.028)\end{array}$ & $\begin{array}{l}0.093 * * * \\
(0.028)\end{array}$ \\
\hline High educated & $\begin{array}{l}0.021 * \\
(0.012)\end{array}$ & $\begin{array}{l}0.025 * * \\
(0.012)\end{array}$ & $\begin{array}{l}0.022 \\
(0.016)\end{array}$ & $\begin{array}{l}0.086 * * \\
(0.039)\end{array}$ & $\begin{array}{l}0.088 * * \\
(0.039)\end{array}$ \\
\hline Foreign & $\begin{array}{l}-0.062^{* *} \\
(0.029)\end{array}$ & $\begin{array}{l}-0.060 * * \\
(0.029)\end{array}$ & $\begin{array}{l}-0.034 \\
(0.044)\end{array}$ & $\begin{array}{l}-0.352^{* * *} \\
(0.127)\end{array}$ & $\begin{array}{l}-0.351^{* * *} \\
(0.126)\end{array}$ \\
\hline Industry experience & $\begin{array}{l}0.017 * * \\
(0.007)\end{array}$ & $\begin{array}{l}0.017 * * * \\
(0.007)\end{array}$ & $\begin{array}{l}0.028^{* * *} \\
(0.008)\end{array}$ & $\begin{array}{l}0.054 * * * \\
(0.018)\end{array}$ & $\begin{array}{l}0.054 * * * \\
(0.018)\end{array}$ \\
\hline Managerial experience & $\begin{array}{l}-0.016 \\
(0.014)\end{array}$ & $\begin{array}{l}-0.012 \\
(0.014)\end{array}$ & $\begin{array}{l}-0.008 \\
(0.015)\end{array}$ & $\begin{array}{l}0.158 * * * \\
(0.045)\end{array}$ & $\begin{array}{l}0.161 * * * \\
(0.045)\end{array}$ \\
\hline Entrepreneurial experience & $\begin{array}{l}0.011 \\
(0.014)\end{array}$ & $\begin{array}{l}0.007 \\
(0.014)\end{array}$ & $\begin{array}{l}0.012 \\
(0.015)\end{array}$ & $\begin{array}{l}-0.080 * \\
(0.045)\end{array}$ & $\begin{array}{l}-0.083^{*} \\
(0.045)\end{array}$ \\
\hline Purchasing power & $\begin{array}{l}-0.703 \\
(0.790)\end{array}$ & $\begin{array}{l}-1.635^{*} \\
(0.865)\end{array}$ & $\begin{array}{l}-1.542 \\
(1.196)\end{array}$ & $\begin{array}{l}-47.135^{* * *} \\
(2.031)\end{array}$ & $\begin{array}{l}-48.399 * * * \\
(2.114)\end{array}$ \\
\hline Population density & $\begin{array}{l}-0.079 \\
(0.129)\end{array}$ & $\begin{array}{l}0.409 * \\
(0.224)\end{array}$ & $\begin{array}{l}0.626^{*} \\
(0.328)\end{array}$ & $\begin{array}{l}0.017 \\
(0.431)\end{array}$ & $\begin{array}{l}0.268 \\
(0.450)\end{array}$ \\
\hline Constant & $\begin{array}{l}1.521 * \\
(0.792)\end{array}$ & $\begin{array}{l}-1.309 \\
(1.324)\end{array}$ & $\begin{array}{l}-2.649 \\
(1.925)\end{array}$ & $\begin{array}{l}10.514 * * * \\
(2.690)\end{array}$ & $\begin{array}{l}9.176 * * * \\
(2.782)\end{array}$ \\
\hline$N$ observations & 20,023 & 20,023 & 10,601 & 116,588 & 116,588 \\
\hline
\end{tabular}


Table 7 (continued)

\begin{tabular}{|c|c|c|c|c|c|}
\hline & \multicolumn{3}{|c|}{ Survival } & \multicolumn{2}{|c|}{ Productivity } \\
\hline & \multicolumn{2}{|c|}{ All entrepreneurs } & \multirow{2}{*}{$\begin{array}{l}\text { Novice entrepreneurs } \\
\text { (3) } \\
\text { IV }\end{array}$} & \multicolumn{2}{|c|}{ All entrepreneurs } \\
\hline & $\begin{array}{l}\text { (1) } \\
\text { OLS }\end{array}$ & $\begin{array}{l}\text { (2) } \\
\text { IV }\end{array}$ & & $\begin{array}{l}(4) \\
\text { OLS }\end{array}$ & $\begin{array}{l}\text { (5) } \\
\text { IV }\end{array}$ \\
\hline Adjusted $R$-squared & 0.294 & 0.281 & 0.291 & 0.194 & 0.194 \\
\hline Kleibergen-Paap $F$-statistics & & 71.4 & 27.17 & & 426.29 \\
\hline
\end{tabular}

All models include municipality and industry fixed effects and a quadratic time trend. In columns (2), (3), and (5), treated municipalities are instrumented using a dummy variable that equals one if the mayor elected belonged to PSD party. Columns (1), (2), (4), and (5) present the results for the full sample of entrepreneurs while columns (3) presents the results for novice entrepreneurs. The symbols $*$, **, and $* * *$ represent significance levels of $10 \%, 5 \%$, and $1 \%$, respectively

operating in the informal sector. To investigate concerns, that the results on performance and type of entrepreneurs were driven by informal entrepreneurs, we estimate our previous analyses on the sample of novice entrepreneurs. The results on survival and type of entrepreneurs are presented in column (3) of Table 7 and column (4) of Table 8 . In the novice entrepreneurs' sample, the introduction of the tax reform is associated with an increase on start-up survival using both specifications (OLS and IV) and sales per employee only in the OLS specification. Novice entrepreneurs have similar sociodemographic characteristics: they are more likely to be female, relatively older, and better educated.

Additionally, there could be a concern that the tax reform might have led incumbent firms to close their operations in coastal municipalities and instead open a new firm in the inland municipalities. To address this concern, we evaluate the effect of the reform on the exit rate of established firms. The results are presented in Appendix 3, Table 16. The coefficient is not statistically significant. Therefore, our exercise provides evidence that the positive impact of the tax reform is not due to firm migration.

\subsection{Robustness check}

Our first robustness exercise runs Eq. (1) for the full sample of Portuguese mainland municipalities (Appendix 3, Table 17). This specification includes the 161 municipalities which reduced their corporate tax rates in 2001, and also 98 non-eligible municipalities. The results remain similar to the baseline.

Furthermore, we also compute three additional exercises (see Appendix 3, Table 18). First, we include the year 2000, which was the year when the reform was firstly announced, although it only entered into effect in the year 2001. Second, we include the year 2000, and change the Post Period variable to equal one for the years after 2000. Third, we remove the most severe crisis year from our sample (2011), which was when Portugal requested a bailout programme. These findings further support our baseline specifications.

Our results are still robust if we use a different time trend (linear and cubic), or if we apply different estimation models (Probit and IV Probit), ${ }^{19}$ or even when we include other control variables, such as: a corruption perception index; a country's trade openness ratio; a tax evasion ratio, or; the "one-stop-shop" reform (Branstetter et al. 2014). Lastly, we used average wages as an alternative measure of performance. The coefficient associated with the reform adoption is positive, although it is not statistically significant.

\section{Discussion and conclusions}

Policymakers around the world reduce corporate tax rates to promote firm formation and job creation. The literature also points out that reducing taxes is perceived to be an effective tool to encourage firm creation and employment. Nevertheless, ambiguity still exists regarding the type of ventures and entrepreneurs which take advantage of such tax reductions.

This study uses micro-level data for the period between 1997 and 2011 to analyse the effects of a Portuguese tax reform on entrepreneurial activity. Portugal's

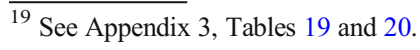


Table 8 The impact of the tax reform on the decision to transition to entrepreneurship

\begin{tabular}{|c|c|c|c|c|}
\hline & \multicolumn{2}{|c|}{ All entrepreneurs } & \multicolumn{2}{|c|}{ Novice entrepreneurs } \\
\hline & (1) & $(2)$ & (3) & (4) \\
\hline Treated $\times$ post period & $\begin{array}{l}0.318 * * * \\
(0.015)\end{array}$ & $\begin{array}{l}0.286 * * * \\
(0.016)\end{array}$ & $\begin{array}{l}0.160 * * * \\
(0.010)\end{array}$ & $\begin{array}{l}0.142 * * * \\
(0.011)\end{array}$ \\
\hline Gender (male) & $\begin{array}{l}0.002 * * * \\
(0.000)\end{array}$ & $\begin{array}{l}0.005^{* * * *} \\
(0.000)\end{array}$ & $\begin{array}{l}0.001 * * * \\
(0.000)\end{array}$ & $\begin{array}{l}0.002 * * * \\
(0.000)\end{array}$ \\
\hline Age $30-39$ & $\begin{array}{l}0.001 * * * \\
(0.000)\end{array}$ & $\begin{array}{l}-0.003 * * * \\
(0.000)\end{array}$ & $\begin{array}{l}0.000 * * * \\
(0.000)\end{array}$ & $\begin{array}{l}-0.002 * * * \\
(0.000)\end{array}$ \\
\hline Age $40-49$ & $\begin{array}{l}0.001 * * * \\
(0.000)\end{array}$ & $\begin{array}{l}-0.006^{* * * *} \\
(0.001)\end{array}$ & $\begin{array}{l}-0.000^{* *} \\
(0.000)\end{array}$ & $\begin{array}{l}-0.004 * * * \\
(0.000)\end{array}$ \\
\hline Age $50-60$ & $\begin{array}{l}0.001 * * * \\
(0.000)\end{array}$ & $\begin{array}{l}-0.009 * * * \\
(0.001)\end{array}$ & $\begin{array}{l}-0.000 * * * \\
(0.000)\end{array}$ & $\begin{array}{l}-0.004 * * * \\
(0.001)\end{array}$ \\
\hline Low educated & $\begin{array}{l}0.002 * * * \\
(0.000)\end{array}$ & $\begin{array}{l}-0.004 * * * \\
(0.000)\end{array}$ & $\begin{array}{l}0.001 * * * \\
(0.000)\end{array}$ & $\begin{array}{l}-0.002 * * * \\
(0.000)\end{array}$ \\
\hline Medium educated & $\begin{array}{l}0.003 * * * \\
(0.000)\end{array}$ & $\begin{array}{l}-0.000 \\
(0.001)\end{array}$ & $\begin{array}{l}0.002 * * * \\
(0.000)\end{array}$ & $\begin{array}{l}-0.001 * \\
(0.000)\end{array}$ \\
\hline High educated & $\begin{array}{l}0.004 * * * \\
(0.000)\end{array}$ & $\begin{array}{l}0.003 * * * \\
(0.001)\end{array}$ & $\begin{array}{l}0.000 * * \\
(0.000)\end{array}$ & $\begin{array}{l}-0.001 * * \\
(0.001)\end{array}$ \\
\hline Foreign & $\begin{array}{l}-0.002 * * * \\
(0.000)\end{array}$ & $\begin{array}{l}0.092 * * * \\
(0.022)\end{array}$ & $\begin{array}{l}-0.001 * * * \\
(0.000)\end{array}$ & $\begin{array}{l}0.050 * * * \\
(0.014)\end{array}$ \\
\hline Hourly wage & & & $\begin{array}{l}0.003 * * * \\
(0.000)\end{array}$ & $\begin{array}{l}0.003 * * * \\
(0.000)\end{array}$ \\
\hline Gender $($ male $) \times$ treated $\times$ post period & & $\begin{array}{l}-0.021 * * * \\
(0.002)\end{array}$ & & $\begin{array}{l}-0.010 * * * \\
(0.002)\end{array}$ \\
\hline Age $30-39 \times$ treated $\times$ post period & & $\begin{array}{l}0.025 * * * \\
(0.003)\end{array}$ & & $\begin{array}{l}0.012 * * * \\
(0.002)\end{array}$ \\
\hline Age $40-49 \times$ treated $\times$ post period & & $\begin{array}{l}0.047 * * * \\
(0.004)\end{array}$ & & $\begin{array}{l}0.022 * * * \\
(0.003)\end{array}$ \\
\hline Age $50-60 \times$ treated $\times$ post period & & $\begin{array}{l}0.061 * * * \\
(0.006)\end{array}$ & & $\begin{array}{l}0.024 * * * \\
(0.004)\end{array}$ \\
\hline Low educated $\times$ treated $\times$ post period & & $\begin{array}{l}0.034 * * * \\
(0.003)\end{array}$ & & $\begin{array}{l}0.015 * * * \\
(0.002)\end{array}$ \\
\hline Medium educated $\times$ treated $\times$ post period & & $\begin{array}{l}0.021 * * * \\
(0.004)\end{array}$ & & $\begin{array}{l}0.013 * * * \\
(0.003)\end{array}$ \\
\hline High educated $\times$ treated $\times$ post period & & $\begin{array}{l}0.017 * * * \\
(0.004)\end{array}$ & & $\begin{array}{l}0.010 * * * \\
(0.003)\end{array}$ \\
\hline Foreign $\times$ treated $\times$ post period & & $\begin{array}{l}-0.575^{* * * *} \\
(0.135)\end{array}$ & & $\begin{array}{l}-0.311 * * * \\
(0.086)\end{array}$ \\
\hline Purchasing power & $\begin{array}{l}-1.175^{* * * *} \\
(0.058)\end{array}$ & $\begin{array}{l}-1.239 * * * \\
(0.071)\end{array}$ & $\begin{array}{l}-0.589 * * * \\
(0.039)\end{array}$ & $\begin{array}{l}-0.614 * * * \\
(0.048)\end{array}$ \\
\hline Population density & $\begin{array}{l}0.593 * * * \\
(0.028)\end{array}$ & $\begin{array}{l}0.583 * * * \\
(0.037)\end{array}$ & $\begin{array}{l}0.295 * * * \\
(0.019)\end{array}$ & $\begin{array}{l}0.283 * * * \\
(0.025)\end{array}$ \\
\hline Constant & $\begin{array}{l}-3.461 * * * \\
(0.162)\end{array}$ & $\begin{array}{l}-3.399 * * * \\
(0.214)\end{array}$ & $\begin{array}{l}-1.724 * * * \\
(0.108)\end{array}$ & $\begin{array}{l}-1.651 * * * \\
(0.144)\end{array}$ \\
\hline
\end{tabular}


Table 8 (continued)

All entrepreneurs

(1)

$6,157,034$

626.7
Novice entrepreneurs

(3)

(4)

$5,395,173$

$5,395,173$

Kleibergen-Paap $F$-statistics

$6,157,034$

446.7

1.485

All models include municipality and industry fixed effects, and quadratic time trend. Columns (1)-(3) present the results for the full sample of entrepreneurs. Columns (4)-(5) present the results for novice entrepreneurs. Treated municipalities are instrumented using a dummy variable that equals one if the mayor elected belonged to PSD party. The omitted categories are founders aged 20-29, with "very low education". The symbols *, **, and $* * *$ represent significance levels of $10 \%, 5 \%$, and $1 \%$, respectively

tax policy experienced a reform in 2001, which aimed to favour firm creation and job formation in specific lessdeveloped regions. This reform reduced taxes to $25 \%$ for start-ups established in inland municipalities, while coastal municipality start-ups were liable to a $32 \%$ rate. Similar to previous studies, we investigate the impact of corporate taxes on firm formation and job creation. However, in contrast, we take the additional step of exploring the characteristics of the founders and of the start-ups which took advantage of this reform.

We find evidence that reducing taxes can lead to an increase in firm formation and job creation. Our results suggest that in the municipalities targeted by the tax policy, the Portuguese tax reform increased firm entry by approximately 41 percentage points and new firm job creation by 24 percentage points, on a monthly basis. Importantly, we also find that the start-ups created in response to the reform are relatively larger (between three to ten employees), are headed by better-educated individuals, are more likely on average to survive their first 3 years, and are more productive. In addition, our results are consistent with a plethora of robustness exercises and falsification tests.

These findings suggest that corporate taxation is an imperative constraint for entrepreneurship - in particular for high-quality entrepreneurs, as it is these who are more easily able to overcome the hurdles of tax legislation and acquire resources to start their ventures, and consequently perform better. Nonetheless, a reduction in corporate taxes could also reflect a change in individuals' risk setting, by making it more attractive for riskaverse individuals to attempt being an entrepreneur. As the nonpecuniary benefits associated with business ownership are large, entrepreneurship could be considered to be a luxury good (Hamilton 2000), particularly for better-educated and wealthier individuals. However, the survival and productivity results seem to strengthen our interpretation that better-educated individuals are more able to take advantage of a tax cut and undermine the luxury good explanation.

We find that the tax reform introduces start-ups into the construction and wholesale and retail sectors. There is nevertheless recognition that the informal economy plays a major role in these industries. The tax reform might have provided the opportunity for some informal entrepreneurs to transition to the formal economy. Furthermore, although we find that half of the new firms created were established by novice entrepreneurs, we cannot completely rule out the informality explanation. However, our survival and type of entrepreneurs' results still hold when we restrict our sample to novice entrepreneurs, suggesting that the tax reform introduces to the market high-quality novice entrepreneurs. Another explanation is that these industries are subject to lower barriers to entry and require less capital to start their activity. They rely mostly on labour, as highlighted by our results regarding firm size. Start-ups created after the reform are relatively larger. Better-educated individuals have greater skills to take advantage of the opportunity created by the tax reform and assemble a larger team. Our results continue to highlight that highly educated individuals are more able to take advantage of the tax reform as they can more easily assemble the required resources.

Our conclusions must be presented with some caveats. First, our study only evaluates the short-term impact of the tax reform, although, of course, we also have to account for possible long-run effects. Second, we do not investigate the amount of taxes which are effectively paid by the new ventures which were created 
on account of the reforms. Entrepreneurs could evade or use various tactics to avoid paying taxes. Nevertheless, past studies show that the effects of marginal and effective corporate taxes on entrepreneurial activity are of a similar magnitude (Djankov et al. 2010). In addition, we do not evaluate the complexity of the tax code introduced by the tax reform, and third, we do not account for changes in taxes at the personal income level. Although personal income tax reduced over time, its reduction was less significant than that which affected corporate taxes. Therefore, our results probably underestimate the real impact of the reform and just represent the lower boundary of the effect of the tax reform. Neither do we consider changes in capital income or capital gains taxes.

The results of our study are in line with those of Darnihamedani et al. (2018), who find a negative relationship between corporate taxes and innovative entrepreneurship. However, we contribute to a better understanding of the level of success of the new ventures created due to tax reductions and we explore the characteristics of both the founders and of the start-ups which take advantage of tax reforms. Our findings are not restricted to just the Portuguese context, as governments are still implementing policies to encourage entrepreneurial activity without a complete understanding of their effects on economic growth and firm creation. Accordingly, to enable governments to design better policies, more research needs to be carried out regarding the extent to which corporate taxes influence entrepreneurial activity.

Acknowledgements The authors are grateful to the Portuguese Ministry of Employment and Social Security and Gabinete de Estratégia e Planeamento (GEP) for giving access to the matched employer-employee data. This work was supported by the FCT (Fundação para a Ciência e a Tecnologia) [grant number UIDB/ 04521/2020]. We would also like to thank the suggestions and comments from two anonymous reviewers, Rui Baptista, and from participants at the 5th LEED Workshop, 2nd International ZEW CoDE II, Mannheim, and 3rd INBAM Conference. The opinions expressed herein are those of the authors and not necessarily those of their employers or of any branch or agency of the Government of Portugal. Barros acknowledges the support of FCT's Doctoral Grant SFRH/BD/77985/2011 and Raposo acknowledges the support of FCT's grant PTDC/EGE-OGE/28603/2017.

\section{Appendix 1. Legislative process}

Table 9 Chronology of the legislative process

Name Description

Law No. 127-B/97, December This law authorizes the $20^{\text {th }}$ (State Budget 1998) government to create an incentive system which is applicable to micro and small firms.

Members' bill (Projeto de Lei) The main opposition political No. $522 /$ VII, May $13^{\text {th }}$, party in the Portuguese 1998

Law No. 171/99, September $18^{\text {th }}$ Parliament (PSD) presented a bill for an incentive system to encourage the location of new firms in the inland region of Portugal.

This law establishes the Portuguese tax incentives for inlandness to enter into force on January $1^{\text {st }}, 2000$, and defines the general criteria for municipalities to qualify for these tax incentives.

Law No. 30-C/2000, December $29^{\text {th }}$

Circular-Letter No. 147, March $30^{\text {th }}, 2001$

Decree-Law No. 310/2001, December $10^{\text {th }}$

Ministerial Order No. 2086/2001, December $13^{\text {th }}$

Ministerial Order No. 1467-A/2001, December $31^{\text {st }}$
The Portuguese Parliament establishes a deadline of 60 days for the government to define objective criteria and issues the list of eligible municipalities. It also reviewed the corporate income tax rate applicable to eligible municipalities (amending Law No. 171/99).

The preliminary issue of the list of eligible municipalities. Establishes the effective date of entering into force-January $1^{\text {st }}, 2001$.

Defines some rules to ensure the proper implementation of the tax incentives. This follows the 'no objection' decision of the European Commission regarding these tax incentives.

This Ministerial Order determines (again) eligibility criteria and eligible municipalities.

Definition of eligibility criteria and eligible municipalities (the same content as Ministerial Order No. 2086/2001). 
Table 9 (continued)

\begin{tabular}{|c|c|}
\hline Name & Description \\
\hline $\begin{array}{l}\text { Ministerial Order No. } \\
170 / 2002, \text { February } 28^{\text {th }}\end{array}$ & $\begin{array}{l}\text { Following the European } \\
\text { Commission's decision } \\
\text { regarding the tax incentives, } \\
\text { this Ministerial Order } \\
\text { publishes excluded industries, } \\
\text { as well as the limit of } \\
\text { incentives per region and per } \\
\text { firm. }\end{array}$ \\
\hline $\begin{array}{l}\text { Law No. } 55-\mathrm{B} / 2004 \text {, } \\
\text { December } 30^{\text {th }}\end{array}$ & $\begin{array}{l}\text { Incorporates the tax incentives } \\
\text { for inlandness into the } \\
\text { Portuguese Tax Benefits } \\
\text { Code. Lowers even further the } \\
\text { corporate income tax rate } \\
\text { applicable to eligible } \\
\text { municipalities in the inland } \\
\text { region. Established different } \\
\text { reduced corporate income tax } \\
\text { rates for existing and new } \\
\text { firms. Entered into force in } \\
2005 \text {. }\end{array}$ \\
\hline $\begin{array}{l}\text { Law No. } 67-\mathrm{A} / 2007 \text {, } \\
\text { December } 31^{\text {st }}\end{array}$ & $\begin{array}{l}\text { Lowers even further the } \\
\text { corporate income tax rate } \\
\text { applicable to eligible } \\
\text { municipalities in the inland } \\
\text { region, entering into force in } \\
2008 \text {. }\end{array}$ \\
\hline $\begin{array}{l}\text { Decree-Law No. } 55 / 2008 \text {, } \\
\text { March } 26^{\text {th }}\end{array}$ & $\begin{array}{l}\text { Adjusts the eligibility criteria for } \\
\text { the tax incentives to } \\
\text { inlandness. }\end{array}$ \\
\hline $\begin{array}{l}\text { Ministerial Order No. } \\
1117 / 2009 \text {, September } 30^{\text {th }}\end{array}$ & $\begin{array}{l}\text { The issue of a new list of eligible } \\
\text { municipalities (much the same } \\
\text { as the previous list). Entered } \\
\text { into force from } 2009 \text { onwards } \\
\text { (as set by Decree-Law No. } \\
\text { 55/2008). }\end{array}$ \\
\hline $\begin{array}{l}\text { Law No. } 64-\mathrm{B} / 2011 \text {, } \\
\text { December } 30^{\text {th }}\end{array}$ & $\begin{array}{l}\text { Abolishes the Portuguese tax } \\
\text { incentives to inlandness after } \\
2011 \text {. }\end{array}$ \\
\hline
\end{tabular}

\section{Appendix 2. Data and construction of variables}

\section{Quadros de Pessoal}

The matched employer-employee dataset (Quadros de Pessoal or SISED - Sistema de Informação de Salários, Emprego e Duração do Trabalho) is a mandatory survey submitted annually in October by all firms with at least one employee. This database collects information from an average of 227,000 firms and 2,000,000 individuals per year, covering virtually all employees and firms in the Portuguese private sector.

This database is generally available annually from 1982 onwards. However, we restrict our analysis to the period between 2001 and 2011. Data are unavailable for the year 2000 .

The database contains three related sets of records: one at the firm level, another at the establishment level, and the last at the employee level. Employees, firms, and establishments are cross-referenced by a unique identifier. Each year, firms are obliged to report their year of incorporation, location, i.e., county (concelho) or municipality where the main offices are located, primary industry, number of employees, number of establishments, initial capital, ownership structure, and sales. At the establishment level, firms have to report the number of employees, location, and primary industry. At the individual level, the database contains information regarding gender, age, date of hire, education, occupation, working hours, and October's earnings. However, the employee records include redundant data and/ or data with frequent changes in gender and/or year of birth for individual employees. We consider these observations to be errors, which arose from individuals incorrectly introducing their identification number or this number being wrongly identified by the respondent.

From the firm and employee databases, we construct the following variables:

Year of foundation is computed as being the minimum of the year of creation reported in the database, the year that the firm first appeared in the database, and the year of the hire of the first employee.

The month of foundation is computed as being the month of the hire of the first employee when the year of hire coincides with the year of foundation.

Survival is an indicator variable which equals one for start-ups that survived their first 3 years. Firms are classified as non-survivors if they do not appear in the database in the following years. Firms can also fail to appear in the database, even if they remain going concerns. For instance, a firm might fail to submit the survey by the due date for two consecutive years. However, by using data from previous years, we were able to estimate that the probability of such a non-response occurring in two successive years is less than $1 \%$.

Size is the start-up's initial number of employees. This measure is computed as being the total number of individuals in the employee records at the beginning of the foundation year. 
Gender is a dummy variable equalling one for men, and zero for women.

Age is coded in years in the database. We define four categories of variables: Age 20-29 is coded one for individuals with age between 20 and 29; Age 30-39 is coded one for individuals with age between 30 and 39; Age 40-49 is coded one for individuals with age between 40 and 49; Age 50-60 is coded one for individuals with age between 50 and 60 .

Education is measured with four categories of variables: high education is a dummy variable equalling one for founders with a Bachelors, Masters, or $\mathrm{PhD}$ degree; medium education is a dummy variable equalling one for individuals who report holding a high school diploma or a vocational school degree; low education is a dummy variable equalling one for individuals who only attended junior high school, and very low education is a dummy variable equalling one for individuals who never attended or completed elementary school.

Industry Experience is coded one for entrepreneurs with experience in the same industry as that of the firms that they founded (four-digit level). Industry classification changed in both 1994 and 2007, and therefore, there is no unequivocal relation between the old and new codes. To mitigate errors, we use all unique relations to translate old to new codes and, vice versa. We then compute the variable industry experience for the new and old codes and aggregate both results. As an alternative, we also use an algorithm, which is based on how the majority of firms changed industry codes from 1994 to 1995 to translate old into new codes. For 2007, this problem is mitigated due to the fact that the database provides information regarding both the new and old industry classification.

Table 10 Variables' Name and Definitions

\section{Municipality level}

\begin{tabular}{|c|c|}
\hline Entry rate & $\begin{array}{l}\text { a Entry rate (business stock approach) is } \\
\text { measured as the number of new firms in } \\
\text { month } m \text { of year } t \text {, divided by the } \\
\text { number of incumbent firms in month } m \\
\text { of year } t-1 \text {, multiplied by } 100 \text {. }\end{array}$ \\
\hline
\end{tabular}

New firm job a New firm job creation is measured by the creation number of jobs created by new firms in month $m$ of year $t$, divided by the total workforce in month $m$ of year $t-1$, multiplied by 100 .

Treated

- Treated is a dummy variable, equalling one if the start-up is established in an inland
Table 10 (continued)

\begin{tabular}{|c|c|}
\hline & $\begin{array}{l}\text { borderline (eligible) municipality, and } \\
\text { zero otherwise. }\end{array}$ \\
\hline Post period & $\begin{array}{l}\text { - Post Period is a dummy variable, equalling } \\
\text { one from } 2001 \text { onwards, and zero } \\
\text { otherwise. }\end{array}$ \\
\hline $\begin{array}{l}\text { Purchasing } \\
\text { power }\end{array}$ & $\begin{array}{l}\text { b Purchasing power is the annual per capita } \\
\text { purchasing power by municipality } \\
\text { retrieved from Statistics Portugal (INE). }\end{array}$ \\
\hline $\begin{array}{l}\text { Population } \\
\text { density }\end{array}$ & $\begin{array}{l}\text { b Population density is the logarithm of } \\
\text { annual average population per perimeter } \\
\text { territory in } \mathrm{Km} \text {. }\end{array}$ \\
\hline PS party & $\begin{array}{l}\text { c PS party is a dummy variable equalling one } \\
\text { if the mayor is from the same political } \\
\text { party as the government (PS), and zero } \\
\text { otherwise. }\end{array}$ \\
\hline PSD party & $\begin{array}{l}\text { c PSD party is a dummy variable, equalling } \\
\text { one if the mayor is from the main } \\
\text { opposition party ( } P S D) \text {, and zero } \\
\text { otherwise. }\end{array}$ \\
\hline $\mathrm{T} 1$ & $\begin{array}{l}\text { - Period } 1 \text { (T1) is a dummy variable equal- } \\
\text { ling one for the period between } 2001 \\
\text { and } 2004, \text { and zero otherwise. }\end{array}$ \\
\hline $\mathrm{T} 2$ & $\begin{array}{l}\text { - Period } 2 \text { (T2) is a dummy variable equal- } \\
\text { ling one for the period between } 2005 \\
\text { and } 2007, \text { and zero otherwise. }\end{array}$ \\
\hline $\mathrm{T} 3$ & $\begin{array}{l}\text { - Period } 3 \text { (T3) is a dummy variable equal- } \\
\text { ling one for the period between } 2008 \\
\text { and } 2011 \text {, and zero otherwise. }\end{array}$ \\
\hline
\end{tabular}

\section{Firm level}

Productivity

Employees

Firm age

Founders

Survival

Initial size

\section{Founder level}

Gender (male)

Age 20-29

Age 30-39

Age 40-49 a Productivity is the logarithm of sales per employee

a Number of employees in each year

a Firm age is the logarithm of the age of the firm, plus one

a Founders is the number of founders

a Survival is a dummy variable equalling one if the firm survives the first 3 years, and zero otherwise

a Initial size is the logarithm of the initial number of employees

Gender (male) is a dummy variable equalling one for men founders, and zero for women founders.

a Age 20-29 is a dummy variable equalling one if the founder's age is between 20 and 29 , and zero otherwise.

a Age 30-39 is a dummy variable equalling one if the founder's age is between 30 and 39 , and zero otherwise.

a Age 40-49 is a dummy variable equalling one if the founder's age is between 40 and 49 , and zero otherwise. 
Table 10 (continued)

\begin{tabular}{|c|c|c|}
\hline Age $50-60$ & $\mathrm{a}$ & $\begin{array}{l}\text { Age } 50-60 \text { is a dummy variable equalling } \\
\text { one if the founder's age is between } 50 \text { and } \\
60 \text {, and zero otherwise. }\end{array}$ \\
\hline $\begin{array}{l}\text { Very low } \\
\text { education }\end{array}$ & $\mathrm{a}$ & $\begin{array}{l}\text { Very low education is a dummy variable } \\
\text { equalling one if the founder never } \\
\text { completed elementary school, and zero } \\
\text { otherwise. }\end{array}$ \\
\hline Low education & $\mathrm{a}$ & $\begin{array}{l}\text { Low education is a dummy variable } \\
\text { equalling one for founders who attended } \\
\text { junior high school, and zero otherwise. }\end{array}$ \\
\hline $\begin{array}{l}\text { Medium } \\
\text { education }\end{array}$ & $\mathrm{a}$ & $\begin{array}{l}\text { Medium education is a dummy variable } \\
\text { equalling one for founders with a high } \\
\text { school diploma or equivalent, and zero } \\
\text { otherwise. }\end{array}$ \\
\hline High education & $\mathrm{a}$ & $\begin{array}{l}\text { High education is a dummy variable } \\
\text { equalling one for founders who report } \\
\text { holding a Bachelor's degree or a more } \\
\text { advanced degree, and zero otherwise. }\end{array}$ \\
\hline Foreign & $\mathrm{a}$ & $\begin{array}{l}\text { Foreign is a dummy variable equalling one } \\
\text { for foreign founders, and zero for } \\
\text { Portuguese founders. }\end{array}$ \\
\hline $\begin{array}{l}\text { Industry } \\
\text { experience }\end{array}$ & $\mathrm{a}$ & $\begin{array}{l}\text { Industry experience is a dummy variable } \\
\text { equalling one for founders who previously } \\
\text { worked in the same four-digit industry digit } \\
\text { code durng the } 5 \text { years before the firm was } \\
\text { founded, and zero otherwise. }\end{array}$ \\
\hline $\begin{array}{l}\text { Managerial } \\
\text { experience }\end{array}$ & $\mathrm{a}$ & $\begin{array}{l}\text { Managerial experience is a dummy } \\
\text { variable equalling one when a founder has } \\
\text { at least } 1 \text { year of top-management experi- } \\
\text { ence during the } 5 \text { years before the firm was } \\
\text { founded, and zero otherwise. }\end{array}$ \\
\hline $\begin{array}{l}\text { Entrepreneurial } \\
\text { experience }\end{array}$ & $\mathrm{a}$ & $\begin{array}{l}\text { Entrepreneurial experience is a dummy } \\
\text { variable equalling one if a founder had any } \\
\text { experience in founding firms during the } \\
5 \text { years previous to founding the firm in } \\
\text { question, and zero otherwise }\end{array}$ \\
\hline
\end{tabular}

${ }^{a}$ Ministry of Solidarity, Employment and Social Security (Quadros de Pessoal dataset). ${ }^{\mathrm{b}}$ INE Portuguese National Statistical Institute. ${ }^{\mathrm{c}} \mathrm{CNE}$ Portuguese National Election Commission

\section{Appendix 3. Additional results}

Table 11 Reduced form for Table 5, column 2

(1) Treated

PSD party

$0.214 * *$

Purchasing power

Population density

$-2.165 * * *$

$N$ observations

11,736

Wald's $F$ test

228.7

Data is measured by month and municipality for the periods 1997 2011. All models include municipality and month fixed effects and a quadratic time trend. Wald's test of exogeneity $(/$ athrho $=0)$ : $\chi^{2}(1)=228.7$; Prob $>\chi^{2}=0.0000$. The symbols *, **, and *** represent significance levels of $10 \%, 5 \%$, and $1 \%$, respectively

Table 12 Correlation between the political dummy (PSD party) and the dependent variables

\begin{tabular}{lll}
\hline & (1) Entry rate & (2) Birth job creation \\
\hline PSD party & -2.444 & -2.913 \\
& $(2.177)$ & $(2.576)$ \\
Purchasing power & -1.444 & -5.281 \\
& $(13.756)$ & $(13.336)$ \\
Population density & 2.325 & 2.824 \\
& $(2.047)$ & $(2.381)$ \\
$N$ observations & 2556 & 2556 \\
Pseudo $R$-squared & 0.028 & 0.051
\end{tabular}

Data is measured by month and municipality for the period 19972011. All models include municipality and month fixed effects and a quadratic time trend. The symbols $*$, **, and *** represent significance levels of $10 \%, 5 \%$, and $1 \%$, respectively 
Table 13 The impact of the tax reform on entry rate: excluding municipalities which changed the political party

(1) Entry rate

\begin{tabular}{ll}
\hline Treated $\times$ post period & $0.387^{*}$ \\
& $(0.208)$ \\
Purchasing power & -0.332 \\
& $(1.585)$ \\
Population density & $1.083^{* *}$ \\
& $(0.527)$ \\
$N$ observations & 11,400 \\
Adjusted $R$-squared & 0.634 \\
Kleibergen-Paap $F$-statistics & 228.7 \\
\hline
\end{tabular}

Data is measured by month and municipality for the period 19972011, excluding municipalities whose mayors belonged to the PS party and then changed to the PSD party. All models include municipality and monthly fixed effects and a quadratic time trend. The symbols *, **, and *** represent significance levels of $10 \%$, $5 \%$, and $1 \%$, respectively

Table 14 The impact of the tax reform on firm entry by knowledge-based firms and level of technological intensity

\begin{tabular}{|c|c|c|c|c|}
\hline & \multicolumn{2}{|l|}{ Knowledge-based firms } & \multicolumn{2}{|l|}{ Technological intensity } \\
\hline & $\begin{array}{l}\text { (1) Knowledge-based } \\
\text { firms }\end{array}$ & $\begin{array}{l}\text { (2) Non-knowledge-based } \\
\text { firms }\end{array}$ & $\begin{array}{l}\text { (3) High and medium- } \\
\text { high }\end{array}$ & $\begin{array}{l}\text { (4) Low and medium- } \\
\text { low }\end{array}$ \\
\hline \multirow[t]{2}{*}{ Treated $\times$ post period } & 0.014 & $0.397^{*}$ & -0.004 & 0.042 \\
\hline & $(0.021)$ & $(0.209)$ & $(0.008)$ & $(0.046)$ \\
\hline \multirow[t]{2}{*}{ Purchasing power } & -0.107 & -0.471 & 0.048 & -0.376 \\
\hline & $(0.290)$ & $(1.520)$ & $(0.085)$ & $(0.345)$ \\
\hline \multirow[t]{2}{*}{ Population density } & 0.053 & $1.063^{* *}$ & -0.001 & 0.132 \\
\hline & $(0.059)$ & $(0.514)$ & $(0.016)$ & $(0.114)$ \\
\hline$N$ observations & 11,736 & 11,736 & 11,736 & 11,736 \\
\hline Adjusted $R$-squared & 0.293 & 0.603 & 0.040 & 0.300 \\
\hline $\begin{array}{c}\text { Kleibergen-Paap } \\
F \text {-statistics }\end{array}$ & 228.7 & 228.7 & 228.7 & 228.7 \\
\hline
\end{tabular}

Data is measured by month and municipality for the period 1997-2011. According to the OECD (2002), technology-based industries can be divided into high and medium-high technology industries (chemicals, machinery and equipment, electrical machinery and apparatus, and transport equipment) and medium-low and low technology industries (food and beverage products, textile and clothing products, leather and footwear, wood and paper products, printing and publishing, rubber and plastic products, other non-metallic mineral products, and basic metals) 
Table 15 Reduced form for Table 7, column 2

(1) Reduced form

PSD party

$0.098 * * *$

(0.012)

Initial size

$-0.001$

(0.001)

Number founders

$0.004^{* *}$

(0.002)

$-0.002$

(0.002)

Age 30-39

0.002

(0.003)

Age 40-49

0.000

(0.003)

Age 50-60

0.006

(0.004)

Low educated

$-0.001$

(0.003)

Medium educated

$-0.003$

(0.004)

High educated

$-0.008^{*}$

(0.005)

Foreign

$-0.006$

(0.004)

Industry experience

$-0.001$

(0.003)

Managerial experience

$-0.012 * *$

(0.005)

Entrepreneurial experience

$0.013 * *$

(0.005)

Purchasing power

$2.761 * * *$

(0.286)

Population density

$-1.313 * * *$

(0.063)

$7.561 * * *$

(0.382)

20,023

$N$ observations

7.33

Wald's $F$ test
Table 16 The impact of the tax reform on established firm exit

(1) Firm exit

Treated $\times$ post period

0.146

(0.484)

Purchasing power

$-16.642$

(17.083)

Population density

$-1.025$

(1.599)

978

$N$ observations

0.082

Adjusted $R$-squared

44.42

The model includes municipality and a quadratic time trend. Treated municipalities are instrumented using a dummy variable that equals one if the mayor elected belonged to the PSD party. The symbols *, **, and $* * *$ represent significance levels of $10 \%$, $5 \%$, and $1 \%$, respectively

The model includes municipality and industry fixed effects and a quadratic time trend. Wald's test of exogeneity $(/$ athrho $=0)$ : $\chi^{2}(1)=71.40$; Prob $>\chi^{2}=0$. The symbols *, **, and $* * *$ represent significance levels of $10 \%, 5 \%$, and $1 \%$, respectively 
Table 17 Robustness checks: Full sample of mainland municipalities

\begin{tabular}{|c|c|c|c|c|c|}
\hline & \multirow{2}{*}{$\begin{array}{l}\text { OLS } \\
\text { (1) Policy }\end{array}$} & \multicolumn{4}{|c|}{ Instrumental variable (IV) estimations } \\
\hline & & (2) Policy & (3) Policy per period & (4) Placebo & (5) After the end of the policy \\
\hline \multicolumn{6}{|l|}{ Panel A: Entry rate } \\
\hline Treated $\times$ post period & $\begin{array}{l}0.134^{* * *} \\
(0.015)\end{array}$ & $\begin{array}{l}0.337^{* * *} \\
(0.112)\end{array}$ & & $\begin{array}{l}0.083 \\
(0.061)\end{array}$ & $\begin{array}{l}-0.351^{\text {**** }} \\
(0.051)\end{array}$ \\
\hline Treated $\times \mathrm{T} 1$ & & & $\begin{array}{l}0.313^{* *} \\
(0.149)\end{array}$ & & \\
\hline Treated $\times \mathrm{T} 2$ & & & $\begin{array}{l}0.265 \\
(0.239)\end{array}$ & & \\
\hline Treated $\times \mathrm{T} 3$ & & & $\begin{array}{l}0.368 \\
(0.319)\end{array}$ & & \\
\hline Purchasing power & $\begin{array}{l}-0.749^{*} \\
(0.408)\end{array}$ & $\begin{array}{l}-1.464^{* *} \\
(0.694)\end{array}$ & $\begin{array}{l}-1.417 \\
(1.706)\end{array}$ & $\begin{array}{l}-0.878 \\
(1.403)\end{array}$ & $\begin{array}{l}0.490 \\
(0.632)\end{array}$ \\
\hline Population density & $\begin{array}{l}0.158^{* * *} \\
(0.074)\end{array}$ & $\begin{array}{l}0.650^{* * *} \\
(0.280)\end{array}$ & $\begin{array}{l}0.706 \\
(0.889)\end{array}$ & $\begin{array}{l}0.838^{*} \\
(0.455)\end{array}$ & $\begin{array}{l}-0.734^{* * * *} \\
(0.121)\end{array}$ \\
\hline Time Range & $1997-2011$ & $1997-2011$ & $1997-2011$ & 1994-1999 & $2001-2012$ \\
\hline Treatment Effect & $2001-2011$ & $2001-2011$ & $2001-2011$ & 1997-1999 & 2012 \\
\hline$N$ Observations & 43,272 & 43,272 & 43,272 & 18,648 & 36,478 \\
\hline Adjusted $R$-squared & 0.599 & 0.596 & 0.597 & 0.627 & 0.558 \\
\hline Kleibergen-Paap $F$-statistics & & 716.3 & 59.7 & 1253.0 & 913.0 \\
\hline \multicolumn{6}{|c|}{ Panel B: New firm job creation } \\
\hline Treated $\times$ post period & $\begin{array}{l}0.075^{\text {**** }} \\
(0.018)\end{array}$ & $\begin{array}{l}0.357^{* *} \\
(0.153)\end{array}$ & & $\begin{array}{c}-0.024 \\
(0.086)\end{array}$ & $\begin{array}{l}-0.269^{\text {**** }} \\
(0.069)\end{array}$ \\
\hline Treated $\times \mathrm{T} 1$ & & & $\begin{array}{l}0.404 \\
(0.260)\end{array}$ & & \\
\hline Treated $\times \mathrm{T} 2$ & & & $\begin{array}{l}0.494 \\
(0.430)\end{array}$ & & \\
\hline Treated $\times \mathrm{T} 3$ & & & $\begin{array}{l}0.612 \\
(0.581)\end{array}$ & & \\
\hline Purchasing power & $\begin{array}{l}-1.405^{* * * *} \\
(0.532)\end{array}$ & $\begin{array}{l}-2.397^{* * *} \\
(0.809)\end{array}$ & $\begin{array}{l}-3.731 \\
(2.884)\end{array}$ & $\begin{array}{l}-0.072 \\
(1.510)\end{array}$ & $\begin{array}{l}-0.477 \\
(0.835)\end{array}$ \\
\hline Population density & $\begin{array}{l}0.064 \\
(0.136)\end{array}$ & $\begin{array}{l}0.746^{* *} \\
(0.368)\end{array}$ & $\begin{array}{l}1.482 \\
(1.592)\end{array}$ & $\begin{array}{c}-0.074 \\
(0.621)\end{array}$ & $\begin{array}{l}-0.495^{* * *} \\
(0.214)\end{array}$ \\
\hline Time range & 1997-2011 & 1997-2011 & $1997-2011$ & 1994-1999 & $2001-2012$ \\
\hline Treatment effect & 2001-2011 & $2001-2011$ & 2001-2011 & 1997-1999 & 2012 \\
\hline$N$ observations & 43,272 & 43,272 & 43,272 & 18,648 & 36,478 \\
\hline Adjusted $R$-squared & 0.273 & 0.268 & 0.263 & 0.294 & 0.259 \\
\hline Kleibergen-Paap $F$-statistics & & 716.3 & 59.7 & 1253.0 & 913.0 \\
\hline
\end{tabular}

Data is measured by month and municipality for the periods 1997-2011 in columns (1) to (3), 1994-1999 in column (4), and 2001-2012 in column (5). We include all mainland municipalities, excluding the Algarve municipalities. In the Algarve region, for the parishes and municipalities targeted for the reform, our data only have information for the parish level after 2003. We also excluded Odivelas, Trofa, and Vizela municipalities, because they were only founded in 1998. All models include municipality and monthly fixed effects and a quadratic time trend. The symbols *,**, and $* * *$ represent significance levels of $10 \%, 5 \%$, and $1 \%$, respectively 
Table 18 Robustness checks: include year 2000, post-period since 2000, and remove 2011

\begin{tabular}{llll}
\hline Entry rate & $\begin{array}{l}\text { (1) Include } \\
\text { 2000 }\end{array}$ & $\begin{array}{l}\text { (2) Post period } \\
\text { since 2000 }\end{array}$ & $\begin{array}{l}\text { (3) Remove } \\
2011\end{array}$ \\
\hline $\begin{array}{l}\text { Treated } \times \text { post } \\
\text { period }\end{array}$ & $0.321^{* *}$ & $0.246^{* *}$ & $0.412^{*}$ \\
Purchasing power & -0.715 & -0.828 & $(0.215)$ \\
& $(1.448)$ & $(1.271)$ & $(1.755)$ \\
Population density & $1.004^{* *}$ & $0.711^{* *}$ & $1.187^{* *}$ \\
& $(0.406)$ & $(0.294)$ & $(0.596)$ \\
$N$ observations & 12,588 & 12,588 & 10,932 \\
Adjusted & 0.638 & 0.638 & 0.663 \\
$\quad R$-squared & & 387.2 & 224.8 \\
Kleibergen-Paap & 444.1 & 3804 \\
$\quad F$-statistics & & & \\
\hline
\end{tabular}

The tax reform was initially scheduled to enter into force in 2000; however, it only came into effect 1 year later. In column (1), we include the year 2000. In column (2), the variable post period starts in 2000 , rather than in 2001. In column (3), we remove the year 2011 to exclude the most severe crisis year from our sample. Data is measured by month and municipality for the periods 19972011. All models include municipality and monthly fixed effects and a quadratic time trend. The symbols *, **, and *** represent significance levels of $10 \%, 5 \%$, and $1 \%$, respectively
Table 19 Robustness checks: Probit and IV Probit models for survival analysis

\begin{tabular}{|c|c|c|c|}
\hline \multirow[t]{2}{*}{ Estimator } & \multicolumn{3}{|l|}{ Survival } \\
\hline & $\begin{array}{l}(1) \\
\text { Probit }\end{array}$ & $\begin{array}{l}(2) \\
\text { Probit }\end{array}$ & $\begin{array}{l}\text { (3) } \\
\text { IV Probit }\end{array}$ \\
\hline Treated $\times$ post period & & $\begin{array}{l}0.159 * \\
(0.091)\end{array}$ & $\begin{array}{l}1.702 * * * \\
(0.655)\end{array}$ \\
\hline Initial size & $\begin{array}{l}0.167 * * * \\
(0.018)\end{array}$ & $\begin{array}{l}0.167 * * * \\
(0.018)\end{array}$ & $\begin{array}{l}0.164 * * * \\
(0.018)\end{array}$ \\
\hline Number founders & $\begin{array}{l}0.057 * * * \\
(0.021)\end{array}$ & $\begin{array}{l}0.056^{* * *} \\
(0.021)\end{array}$ & $\begin{array}{l}0.049 \text { ** } \\
(0.021)\end{array}$ \\
\hline Gender (male) & $\begin{array}{l}0.089 * * * \\
(0.027)\end{array}$ & $\begin{array}{l}0.089 * * * \\
(0.027)\end{array}$ & $\begin{array}{l}0.090 \text { *** } \\
(0.026)\end{array}$ \\
\hline Age $30-39$ & $\begin{array}{l}0.111 * * * \\
(0.029)\end{array}$ & $\begin{array}{l}0.111^{* * * *} \\
(0.029)\end{array}$ & $\begin{array}{l}0.104 * * * \\
(0.029)\end{array}$ \\
\hline Age $40-49$ & $\begin{array}{l}0.144 * * * \\
(0.034)\end{array}$ & $\begin{array}{l}0.144 * * * \\
(0.034)\end{array}$ & $\begin{array}{l}0.139 * * * \\
(0.034)\end{array}$ \\
\hline Age $50-60$ & $\begin{array}{l}0.151 \text { *** } \\
(0.048)\end{array}$ & $\begin{array}{l}0.151 \text { *** } \\
(0.048)\end{array}$ & $\begin{array}{l}0.136^{* * * *} \\
(0.048)\end{array}$ \\
\hline Low educated & $\begin{array}{l}-0.027 \\
(0.034)\end{array}$ & $\begin{array}{l}-0.026 \\
(0.034)\end{array}$ & $\begin{array}{l}-0.025 \\
(0.033)\end{array}$ \\
\hline Medium educated & $\begin{array}{l}0.044 \\
(0.043)\end{array}$ & $\begin{array}{l}0.045 \\
(0.043)\end{array}$ & $\begin{array}{l}0.050 \\
(0.043)\end{array}$ \\
\hline High educated & $\begin{array}{l}0.061 \\
(0.053)\end{array}$ & $\begin{array}{l}0.064 \\
(0.054)\end{array}$ & $\begin{array}{l}0.076 \\
(0.053)\end{array}$ \\
\hline Foreign & $\begin{array}{l}-0.206^{*} \\
(0.106)\end{array}$ & $\begin{array}{l}-0.204^{*} \\
(0.106)\end{array}$ & $\begin{array}{l}-0.186^{*} \\
(0.104)\end{array}$ \\
\hline Industry experience & $\begin{array}{l}0.078 * * \\
(0.031)\end{array}$ & $\begin{array}{l}0.078 * * \\
(0.031)\end{array}$ & $\begin{array}{l}0.078^{* * * *} \\
(0.030)\end{array}$ \\
\hline Managerial experience & $\begin{array}{l}-0.074 \\
(0.066)\end{array}$ & $\begin{array}{l}-0.072 \\
(0.066)\end{array}$ & $\begin{array}{l}-0.053 \\
(0.066)\end{array}$ \\
\hline Entrepreneurial experience & $\begin{array}{l}0.077 \\
(0.069)\end{array}$ & $\begin{array}{l}0.076 \\
(0.069)\end{array}$ & $\begin{array}{l}0.055 \\
(0.068)\end{array}$ \\
\hline Purchasing power & $\begin{array}{l}-2.181 \\
(3.173)\end{array}$ & $\begin{array}{l}-2.580 \\
(3.178)\end{array}$ & $\begin{array}{l}-6.266^{*} \\
(3.474)\end{array}$ \\
\hline Population density & $\begin{array}{l}0.227 \\
(0.531)\end{array}$ & $\begin{array}{l}0.402 \\
(0.535)\end{array}$ & $\begin{array}{l}2.407 * * \\
(1.009)\end{array}$ \\
\hline Constant & $\begin{array}{l}0.705 \\
(3.246)\end{array}$ & $\begin{array}{l}-0.299 \\
(3.265)\end{array}$ & $\begin{array}{l}-11.987 * * \\
(5.967)\end{array}$ \\
\hline$N$ observations & 20,023 & 20,023 & 20,023 \\
\hline
\end{tabular}

All models include municipality and industry fixed effects and a quadratic time trend. In column (3), treated municipalities are instrumented using a dummy variable which equals one if the elected mayor belonged to the PSD party. The symbols *, **, and $* * *$ represent significance levels of $10 \%, 5 \%$, and $1 \%$, respectively 
Table 20 Robustness checks: Probit and IV Probit models for decision to transition to entrepreneurship

\begin{tabular}{|c|c|c|c|c|}
\hline Estimator & $\begin{array}{l}(1) \\
\text { Probit }\end{array}$ & $\begin{array}{l}(2) \\
\text { Probit }\end{array}$ & $\begin{array}{l}\text { (3) } \\
\text { IV Probit }\end{array}$ & $\begin{array}{l}\text { (4) } \\
\text { IV Probit }\end{array}$ \\
\hline Treated $\times$ post period & $\begin{array}{l}0.374 * * * \\
(0.017)\end{array}$ & $\begin{array}{l}0.303 * * * \\
(0.025)\end{array}$ & $\begin{array}{l}6.425 * * * \\
(0.014)\end{array}$ & $\begin{array}{l}5.017 * * * \\
(0.111)\end{array}$ \\
\hline Gender (male) & $\begin{array}{l}0.185 * * * \\
(0.007)\end{array}$ & $\begin{array}{l}0.145 * * * \\
(0.009)\end{array}$ & $\begin{array}{l}0.042 * * * \\
(0.003)\end{array}$ & $\begin{array}{l}0.101 * * * \\
(0.007)\end{array}$ \\
\hline Age $30-39$ & $\begin{array}{l}0.112 * * * \\
(0.006)\end{array}$ & $\begin{array}{l}0.059 * * * \\
(0.009)\end{array}$ & $\begin{array}{l}0.022 * * * \\
(0.002)\end{array}$ & $\begin{array}{l}0.038 * * * \\
(0.006)\end{array}$ \\
\hline Age $40-49$ & $\begin{array}{l}0.110 * * * \\
(0.007)\end{array}$ & $\begin{array}{l}-0.055^{* * *} \\
(0.011)\end{array}$ & $\begin{array}{l}0.024 * * * \\
(0.002)\end{array}$ & $\begin{array}{l}-0.037 * * * \\
(0.007)\end{array}$ \\
\hline Age $50-60$ & $\begin{array}{l}0.020 * * \\
(0.010)\end{array}$ & $\begin{array}{l}-0.252^{* * * *} \\
(0.017)\end{array}$ & $\begin{array}{l}0.011 * * * \\
(0.003)\end{array}$ & $\begin{array}{l}-0.165^{* * *} \\
(0.013)\end{array}$ \\
\hline Low educated & $\begin{array}{l}0.179 * * * \\
(0.007)\end{array}$ & $\begin{array}{l}0.207 * * * \\
(0.010)\end{array}$ & $\begin{array}{l}0.047 * * * \\
(0.003)\end{array}$ & $\begin{array}{l}0.147 * * * \\
(0.008)\end{array}$ \\
\hline Medium educated & $\begin{array}{l}0.308 * * * \\
(0.008)\end{array}$ & $\begin{array}{l}0.295 * * * \\
(0.013)\end{array}$ & $\begin{array}{l}0.078 * * * \\
(0.004)\end{array}$ & $\begin{array}{l}0.208 * * * \\
(0.010)\end{array}$ \\
\hline High educated & $\begin{array}{l}0.434 * * * \\
(0.010)\end{array}$ & $\begin{array}{l}0.152 * * * \\
(0.017)\end{array}$ & $\begin{array}{l}0.104 * * * \\
(0.005)\end{array}$ & $\begin{array}{l}0.109 * * * \\
(0.012)\end{array}$ \\
\hline Foreign & $\begin{array}{l}-0.217 * * * \\
(0.023)\end{array}$ & $\begin{array}{l}-0.249 * * * \\
(0.034)\end{array}$ & $\begin{array}{l}-0.054 * * * \\
(0.006)\end{array}$ & $\begin{array}{l}-0.173 * * * \\
(0.024)\end{array}$ \\
\hline Hourly wage & & $\begin{array}{l}0.399 * * * \\
(0.007)\end{array}$ & & $\begin{array}{l}0.264 * * * \\
(0.010)\end{array}$ \\
\hline Purchasing power & $\begin{array}{l}5.221 * * * \\
(0.674)\end{array}$ & $\begin{array}{l}3.111 * * * \\
(0.948)\end{array}$ & $\begin{array}{l}-22.658 * * * \\
(0.216)\end{array}$ & $\begin{array}{l}-15.593 * * * \\
(0.887)\end{array}$ \\
\hline Population density & $\begin{array}{l}2.515 * * * \\
(0.139)\end{array}$ & $\begin{array}{l}1.997 * * * \\
(0.191)\end{array}$ & $\begin{array}{l}11.573 * * * \\
(0.039)\end{array}$ & $\begin{array}{l}9.577 * * * \\
(0.023)\end{array}$ \\
\hline Constant & $\begin{array}{l}-18.386^{* * *} \\
(0.857)\end{array}$ & $\begin{array}{l}-15.451 * * * \\
(1.169)\end{array}$ & $\begin{array}{l}-68.309 * * * \\
(0.236)\end{array}$ & $\begin{array}{l}-58.415 \\
(0.000)\end{array}$ \\
\hline$N$ observations & $5,831,808$ & $5,063,724$ & $5,831,808$ & $5,063,724$ \\
\hline
\end{tabular}

All models include municipality and industry fixed effects, and a quadratic time trend. Treated municipalities are instrumented using a dummy variable which equals one if the elected mayor belonged to the PSD party. The symbols *, **, and *** represent significance levels of $10 \%, 5 \%$, and $1 \%$, respectively 
Open Access This article is licensed under a Creative Commons Attribution 4.0 International License, which permits use, sharing, adaptation, distribution and reproduction in any medium or format, as long as you give appropriate credit to the original author(s) and the source, provide a link to the Creative Commons licence, and indicate if changes were made. The images or other third party material in this article are included in the article's Creative Commons licence, unless indicated otherwise in a credit line to the material. If material is not included in the article's Creative Commons licence and your intended use is not permitted by statutory regulation or exceeds the permitted use, you will need to obtain permission directly from the copyright holder. To view a copy of this licence, visit http://creativecommons.org/licenses/by/4.0/.

\section{References}

Angrist, J. D., \& Pischke, J. S. (2009). Mostly harmless econometrics: An empiricist's companion. Princeton: Princeton University Press.

Audretsch, D., \& Fritsch, M. (1994). On the measurement of entry rates. Empirica, 21, 105-113.

Bacher, H., \& Brülhart, M. (2012). Progressive taxes and firm births. International Tax and Public Finance, 20, 129-168. https://doi.org/10.1007/s10797-012-9218-z.

Balconi, M., \& Fontana, R. (2011). Entry and innovation: An analysis of the fabless semiconductor business. Small Business Economics, 37(1), 87-106. https://doi.org/10.1007 /s11187-009-9231-5.

Baliamoune-Lutz, M., \& Garello, P. (2014). Tax structure and entrepreneurship. Small Business Economics, 42(1), 165190. https://doi.org/10.1007/s11187-013-9469-9.

Baumol, W. J., Litan, R. E., \& Schramm, C. J. (2007). Good capitalism, bad capitalism, and the economics of growth and prosperity. London: Yale University Press. https://doi. org/10.2139/ssrn.985843.

Belitski, M., Chowdhury, F., \& Desai, S. (2016). Taxes, corruption, and entry. Small Business Economics, 47(1), 201-216. https://doi.org/10.1007/s11187-016-9724-y

Bertrand, M., Duflo, E., \& Mullainathan, S. (2004). How much should we trust differences-in-differences estimates? The Quarterly Journal of Economics, 119(1), 249-275. https://doi.org/10.1162/003355304772839588.

Bhattarai, K., Head, M., Haughton, J., \& Tuerck, D. G. (2017). Simulating corporate income tax reform proposals with a dynamic CGE model. International Journal of Economics and Finance, 9(5), 20-35. https://doi.org/10.5539/ijef.v9n5 p20.

Blau, D. (1987). A time-series analysis of self-employment in the United States. Journal of Political Economy, 95(3), 445-467. https://doi.org/10.1086/261466.

Block, J. (2016). Corporate income taxes and entrepreneurship. Bonn: IZA World of Labor. https://doi.org/10.15185 izawol.257.

Branstetter, L., Lima, F., Taylor, L. J., \& Venâncio, A. (2014). Do entry regulations deter entrepreneurship and job creation? Evidence from recent reforms in Portugal. The Economic
Journal, 124(577), 805-832. https://doi.org/10.1111 lecoj.12044.

Braunerhjelm, P., \& Eklund, J. E. (2014). Taxes, tax administrative burdens and new firm formation. Kyklos, 67(1), 1-11. https://doi.org/10.1111/kykl.12040.

Briscoe, G., Dainty, A., \& Millett, S. (2000). The impact of the tax system on self-employment in the British construction industry. International Journal of Manpower, 21(8), 596-613. https://doi.org/10.1108/01437720010379501.

Bruce, D. (2000). Effects of the United States tax system on transitions into self-employment. Labour Economics, 7, 545-574. https://doi.org/10.1016/S0927-5371(00)00013-0.

Bruce, D. (2002). Taxes and entrepreneurial endurance: Evidence from the self-employed. National Tax Journal, 55, 5-24. https://doi.org/10.17310/ntj.2002.1.01.

Bruce, D., Gurley-Calvez, T., \& Norwood, A. (2020). Taxes and entrepreneurship: A literature review and research agenda. Foundations and Trends in Entrepreneurship, Forthcoming.

Bruce, D., \& Mohsin, M. (2006). Tax policy and entrepreneurship: New time series evidence. Small Business Economics, 26(5), 409-425. https://doi.org/10.1007/s11187-005-5602-8.

Carroll, R., Holtz-Eakin, D., Rider, M., \& Rosen, H. S. (2000). Income taxes and entrepreneurs' use of labor. Journal of Labor Economics, 18(2), 324-351. https://doi.org/10.1086 /209961.

Chen, J. (2013). Selection and serial entrepreneurs. Journal of Economics \& Management Strategy, 22(2), 281-311. https://doi.org/10.1111/jems.12016.

Cowling, M., \& Mitchell, P. (1997). The evolution of UK selfemployment a study of government policy and the role of the macroeconomy. The Manchester School, 65(4), 427-442. https://doi.org/10.1111/1467-9957.00073.

Cullen, J., \& Gordon, R. (2007). Taxes and entrepreneurial risktaking: Theory and evidence for the US. Journal of Public Economics, 91, 1479-1505. https://doi.org/10.1016/j. jpubeco.2006.12.001.

Da Rin, M., Di Giacomo, M., \& Sembenelli, A. (2010). Corporate taxation and the size of new firms: Evidence from Europe. Journal of the European Economic Association, 8(2-3), 606-616. https://doi.org/10.1111/j.1542-4774.2010. tb00530.x.

Da Rin, M., Di Giacomo, M., \& Sembenelli, A. (2011). Entrepreneurship, firm entry, and the taxation of corporate income: Evidence from Europe. Journal of Public Economics, 95(9-10), 1048-1066. https://doi.org/10.1016/j. jpubeco.2010.06.010.

Darnihamedani, P., Block, J. H., Hessels, J., \& Simonyan, A. (2018). Taxes, start-up costs, and innovative entrepreneurship. Small Business Economics, 51(2), 355-369. https://doi. org/10.1007/s11187-018-0005-9.

Djankov, S., Ganser, T., McLiesh, C., Ramalho, R., \& Shleifer, A. (2010). The effect of corporate taxes on investment and entrepreneurship. American Economic Journal: Macroeconomics, 2(3), 31-64. https://doi.org/10.1257 /mac.2.3.31.

Eggers, J. P., \& Song, L. (2014). Dealing with failure: Serial entrepreneurs and the costs of changing industries between ventures. Academy of Management Journal, 58(6), 17851803. https://doi.org/10.5465/amj.2014.0050. 
Fölster, S. (2002). Do lower taxes stimulate self-employment? Small Business Economics, 19(2), 135-145. https://doi. org/10.1023/a:1016200800982.

Fossen, F. M., \& Steiner, V. (2009). Income taxes and entrepreneurial choice: Empirical evidence from two German natural experiments. Empirical Economics, 36(3), 487-513. https://doi.org/10.1007/s00181-008-0208-z.

Gentry, W. M., \& Hubbard, R. G. (2000). Tax policy and entrepreneurial entry. American Economic Review, 90(2), 283287. https://doi.org/10.1257/aer.90.2.283.

Gentry, W. M., \& Hubbard, R. G. (2005). 'Success taxes', entrepreneurial entry, and innovation. Innovation Policy and the Economy, 5, 87-108. https://doi.org/10.1086 /ipe.5.25056172.

Gompers, P., Kovner, A., Lerner, J., \& Scharfstein, D. (2010). Performance persistence in entrepreneurship. Journal of Financial Economics, 96(1), 18-32. https://doi.org/10.1016 /j.jfineco.2009.11.001.

Hamilton, B. (2000). Does entrepreneurship pay? An empirical analysis of the returns to self-employment. Journal of Political Economy, 108(3), 604-631.

Hansson, Å. (2012). Tax policy and entrepreneurship: Empirical evidence from Sweden. Small Business Economics, 38(4), 495-513. https://doi.org/10.1007/s11187-010-9282-7.

Haufler, A., Norbäck, P. J., \& Persson, L. (2014). Entrepreneurial innovations and taxation. Journal of Public Economics, 113, 13-31. https://doi.org/10.1016/j.jpubeco.2014.03.002.

Hellevik, O. (2007). Linear versus logistic regression when the dependent variable is a dichotomy. Quality \& Quantity, 43(1), 59-74. https://doi.org/10.1007/s11135-007-9077-3.

Henrekson, M., \& Sanandaji, T. (2011). The interaction of entrepreneurship and institutions. Journal of Institutional Economics, 7(1), 47-75. https://doi.org/10.1017 /S1744137410000342.

Ilmakunnas, P., Kanniainen, V., \& Lammi, U. (1999). Entrepreneurship, economic risks, and risk-Insurance in the Welfare State : Results with OECD data 1978-93. CESifo Working Paper Series 356. 10419/81981.

Kamleitner, B., Korunka, C., \& Kirchler, E. (2012). Tax compliance of small business owners: A literature review and conceptual framework. International Journal of Entrepreneurial Behavior \& Research, 18(3), 330-351. https://doi. org/10.1108/13552551211227710.

Kihlstrom, R., \& Laffont, J.-J. (1979). A general equilibrium entrepreneurial theory of firm formation based on risk aversion. Journal of Political Economy, 87(4), 719-748.

Kulchina, E., \& Venâncio, A. (2019). Top managers in entrepreneurial firms: Who is running the show?. Available at SSRN 3441999. https://doi.org/10.2139/ssrn.3441999.

Lee, Y., \& Gordon, R. H. (2005). Tax structure and economic growth. Journal of Public Economics, 89(5-6), 1027-1043. https://doi.org/10.1016/j.jpubeco.2004.07.002.
Long, J. (1982a). Income taxation and the allocation of market labor. Journal of Labor Research, 3, 259-276. https://doi. org/10.1007/BF02685189.

Long, J. (1982b). The income tax and self-employment. National Tax Journal, 36, 31-42.

Lucas Jr., R. E. (1978). On the size distribution of business firms. The Bell Journal of Economics, 508-523. https://doi. org $/ 10.2307 / 3003596$.

Moore, R. (1983). Self-employment and the incidence of the payroll tax. National Tax Journal, 36, 491-501.

Moore, R. (2003). The effects of the 1986 and 1993 tax reforms on self-employment. Proceedings of the Ninety-Fifth Annual Conference on Taxation, National Tax Association. https://doi.org/10.2139/ssrn.515144.

Mukherjee, A., Singh, M., \& Žaldokas, A. (2017). Do corporate taxes hinder innovation? Journal of Financial Economics, 124 (1), 195-221. https://doi.org/10.1016/j. jfineco.2017.01.004.

OECD. (2002). OCDE Science, Technology and Industry Outlook. Technical report: OECD.

Parker, S. C. (1996). A time series model of self-employment under uncertainty. Economica, 63, 459-475 https://www. jstor.org/stable/2555017.

Parker, S. C., \& Robson, M. T. (2004). Explaining international variations in self-employment: Evidence from a panel of OECD countries. Southern Economic Journal, 71(2), 287301. https://doi.org/10.2307/4135292.

Robson, M. T. (1998). The rise in self-employment amongst U.K. males. Small Business Economics, 10, 199-212. https://doi. org/10.1023/A:1007990921394.

Rocha, V., Carneiro, A., \& Amorim Varum, C. (2015). Serial entrepreneurship, learning by doing and self-selection. International Journal of Industrial Organization, 40, 91106. https://doi.org/10.1016/j.ijindorg.2015.04.001.

Schuetze, H. J. (2000). Taxes, economic conditions and recent trends in male self-employment: A Canada-US comparison. Labour Economics, 7(5), 507-544. https://doi.org/10.1016 /S0927-5371(00)00012-9.

Shane, S. (2009). Why encouraging more people to become entrepreneurs is bad public policy. Small Business Economics, 33(2), 141-149. https://doi.org/10.1007/s11187-009-9215-5.

Sull, D., \& Eisenhardt, K. (2015). Simple rules: How to thrive in a complex world. Boston: Mariner Books.

Weber, R. (2015). The effect of tax code complexity on entrepreneurship. Journal of Private Enterprise, 30(2), 83-102.

Weisbach, D. A. (2007). The irreducible complexity of firm-level income taxes: Theory and doctrine in the corporate tax. University of Chicago Law \& Economics, Olin working paper no. 327. https://doi.org/10.2139/ssrn.957358.

Publisher's note Springer Nature remains neutral with regard to jurisdictional claims in published maps and institutional affiliations. 